\title{
Gene expression of sternohyoid and diaphragm muscles in type 2 diabetic rats
}

Erik van Lunteren ${ }^{1,2,3^{*}}$ and Michelle Moyer $^{1}$

\begin{abstract}
Background: Type 2 diabetes differs from type 1 diabetes in its pathogenesis. Type 1 diabetic diaphragm has altered gene expression which includes lipid and carbohydrate metabolism, ubiquitination and oxidoreductase activity. The objectives of the present study were to assess respiratory muscle gene expression changes in type 2 diabetes and to determine whether they are greater for the diaphragm than an upper airway muscle.

Methods: Diaphragm and sternohyoid muscle from Zucker diabetic fatty (ZDF) rats were analyzed with Affymetrix gene expression arrays.

Results: The two muscles had 97 and 102 genes, respectively, with at least \pm 1.5 -fold significantly changed expression with diabetes, and these were assigned to gene ontology groups based on over-representation analysis. Several significantly changed groups were common to both muscles, including lipid metabolism, carbohydrate metabolism, muscle contraction, ion transport and collagen, although the number of genes and the specific genes involved differed considerably for the two muscles. In both muscles there was a shift in metabolism gene expression from carbohydrate metabolism toward lipid metabolism, but the shift was greater and involved more genes in diabetic diaphragm than diabetic sternohyoid muscle. Groups present in only diaphragm were blood circulation and oxidoreductase activity. Groups present in only sternohyoid were immune \& inflammation and response to stress \& wounding, with complement genes being a prominent component.

Conclusion: Type 2 diabetes-induced gene expression changes in respiratory muscles has both similarities and differences relative to previous data on type 1 diabetes gene expression. Furthermore, the diabetic alterations in gene expression differ between diaphragm and sternohyoid.
\end{abstract}

\section{Background}

Diabetes mellitus is one of the most rapidly growing chronic diseases of our time, with human type 2 diabetes becoming more prevalent than type 1 diabetes due to factors such as physical inactivity and increased obesity. Associated with the increasing prevalence of obesity and type 2 diabetes is the growing problem of obstructive sleep apnea and its adverse cardiovascular and neuropsychiatric consequences. Upper airway respiratory muscles are critical for the maintenance of pharyngeal patency during wakefulness and sleep, and for the restoration of pharyngeal patency when obstructive apneas occur during sleep. Many studies in humans and animal models of

\footnotetext{
* Correspondence: exv4@cwru.edu

${ }^{1}$ Pulmonary, Critical Care \& Sleep Division, Department of Medicine, Louis Stokes, Cleveland, USA

2Department of Veterans Affairs Medical Center, Cleveland, OH 44106, USA Full list of author information is available at the end of the article
}

diabetes have confirmed reduced strength and endurance in respiratory and other skeletal muscles, [1-3] which reduces exercise performance and increases dyspnea [4-6]. Interestingly, upper airway muscle contractile properties are affected less than those of the diaphragm by type 1 diabetes, [3,7] although comparable data in type 2 diabetes are lacking.

Several cellular mechanisms underlying limb muscle adverse contractile changes have been identified from biochemical and electrophysiological studies in animal models of diabetes [8-11]. With respect to respiratory muscles, in type 1 diabetic diaphragm the expression of metabolism genes shifted by a small decrease in lipid metabolism gene expression and a large increase in carbohydrate metabolism gene expression; in addition there was increased expression of protein ubiquitination genes (a mechanism of protein breakdown), and increased expression of oxidoreductase genes (indicative of

\section{() Biomed Central}


oxidative stress) [12]. It is unclear if type 2 diabetes affects gene expression of the respiratory muscles in the same manner as type 1 diabetes. Furthermore, it is unknown whether upper airway muscles are affected by diabetes in a similar manner as the diaphragm. However it is known from gene expression studies that compared with the diaphragm, the sternohyoid muscle has higher expression of carbohydrate metabolism genes, as well as lower expression of lipid metabolism genes, especially those involved directly in fatty acid $\beta$ oxidation and biosynthesis in the mitochondria [13]. The hypothesis of the present study is that type 2 diabetes produces substantial changes in gene expression of the upper airway muscles, which furthermore differs both qualitatively and quantitatively from those of the diaphragm.

\section{Methods}

All studies were approved by the institutional animal care and use committee and conformed with $\mathrm{NIH}$ guidelines for animal care. Studies were performed on 11 male Zucker Diabetic Fatty (ZDF) rats, an animal model of obesity and type 2 diabetes, obtained from Charles River Laboratories (Wilmington, MA). All animals had free access to food and water. Obese $(f a / f a)$ animals $(n=5)$ were fed Purina diet \#5008, which induces development of type 2 diabetes between 8 and 12 weeks of age (Corsetti et al. 2000). Lean (+/?) littermates $(n=6)$ were fed normal rodent chow. At an age of eighteen weeks, all animals were well-anesthetized with a mixture of intraperitoneal ketamine, xylazine and acepromazine following an all-night fast. Blood obtained from the tail was analyzed for glucose using a glucometer (Lifescan, Milpitas, CA). The entire sternohyoid and costal diaphragm muscles were removed surgically, placed in RNAlater, and stored at $-80^{\circ} \mathrm{C}$. At the time of muscle removal, fasting blood glucose values were $58 \pm 7 \mathrm{mg} / \mathrm{dl}$ (range 36-77) for the normal animals, and $183 \pm 60 \mathrm{mg} / \mathrm{dl}$ (range 133-275) for the obese ZDF animals ( $\mathrm{P}<0.001$ by unpaired $t$ test). The obese animals had a final weight that was heavier than the lean animals $(424 \pm 28$ vs $348 \pm 5$ grams, for obese and lean, respectively, $\mathrm{P}<0.02$ ). Animals were not treated with insulin or oral hypoglycemics because the purpose of the study was to determine the effects of diabetes on gene expression rather than the extent to which treatment of diabetes would attenuate the changes.

Gene expression array studies were performed in a manner similar to that described previously [14-16]. Total RNA was extracted using Trizol (GibcoBRL, Rockville, $\mathrm{MD})$, and the RNA pellets were resuspended at $1 \mu \mathrm{g}$ RNA/ $\mu$ l DEPC-treated water. This was followed by a cleanup protocol with a Qiagen (Valencia, CA) RNeasy Total RNA mini kit. Total RNA was prepared using Affymetrix (Santa Clara, CA) microarrays, according to the directions from the manufacturer. Briefly, $8 \mu \mathrm{g}$ of
RNA was used in a reverse transcription reaction (SuperScript II; Life Technologies, Rockville, MD) to generate first strand cDNA. After second strand synthesis, double strand cDNA was used in an in vitro transcription reaction to generate biotinylated cRNA, which was purified and fragmented. Next, $15 \mu \mathrm{g}$ of biotinlabeled cRNA was used in a $300 \mu$ l hybridization cocktail which included spiked transcript controls. $200 \mu \mathrm{l}$ of cocktail was loaded onto Affymetrix RAE 230A microarrays (Santa Clara, CA) and hybridized for $16 \mathrm{hr}$ at $45^{\circ} \mathrm{C}$ with agitation. Standard post-hybridization washes and double-stain protocols used an Affymetrix GeneChip Fluidics Station 400. Arrays were scanned using a Hewlett Packard Gene Array scanner, and analyzed with Affymetrix GCOS software. The data have been deposited in NCBIs Gene Expression Omnibus (GEO, http://www.ncbi.nlm.nih.gov/geo/query/acc.cgi?token= jjgprsaqewuayxo\&acc=GSE21791) and assigned Series accession number GSE21791.

Statistical analysis was done with Bayesian analysis of variance for microarrays (BAM), using BAMarray software (http://www.bamarray.com) [17]. BAM balances the number of false detections against false non-detections by means of a special type of inferential regularization (i.e. borrowing strength across the data). Genes were further selected as significant based on consistent and appropriate present and absent calls in all samples per Affymetrix software. Subsequently signals were averaged for muscle from the lean and obese animals, and fold changes were calculated based on average values from each group. Analysis focused on genes whose expression changed at least \pm 1.5 fold in obese compared with lean muscle. To assign biological meaning to the group of genes with changed expression, the subset of genes which met the above criteria was further analyzed with the Gene Ontology (GO) classification system, using DAVID software (http://david.abcc. ncifcrf.gov/) [18]. Over-representation of genes with altered expression within specific GO categories was determined using the one-tailed Fisher exact probability modified by the addition of a jackknifing procedure, which penalizes the significance of categories with very few (eg. one or two) genes and favors more robust categories with larger numbers of genes [19].

Real-time PCR (RT-PCR) was used to confirm changes in gene expression as described previously [14-16]. Testing was done using the same tissue that had been used for gene expression arrays, and was performed on genes which were chosen from the main, statistically overrepresented, GO groupings based on biological interest. An Applied Biosystems ABI 7900HT unit with automation attachment (Foster City, CA) was used for real-time PCR. This unit is capable of collecting spectral data at multiple points during a PCR run. To execute the first step and make archive cDNA, $3 \mu \mathrm{g}$ of total RNA were 
reverse transcribed in a $100 \mu$ l reaction using Applied Biosystems enzymes and reagents in accordance with the manufacturer's protocols. RNA samples were accurately quantitated using a Nanodrop Technologies ND-1000 spectrophotometer (Wilmington, DE). Equal amounts of total RNA were reverse transcribed and then used in PCR amplifications. $\beta$-Actin had very little variation in expression across the sample set and therefore was chosen as the endogenous control. Since many of the target genes of interest were signaling molecules and likely to be expressed at low levels, we opted for a low dilution factor so as to create an environment more conducive to obtaining reliable results. The cDNA reaction from above was diluted by a factor of 10 . For the PCR step, $9 \mu \mathrm{l}$ of this diluted cDNA were used for each of three replicate $15 \mu$ l-reactions carried out in a 384 well plate. Standard PCR conditions were used for the Applied Biosystems assays: $50^{\circ} \mathrm{C}$ for $2 \mathrm{~min}$, followed by $95^{\circ} \mathrm{C}$ for $10 \mathrm{~min}$, followed by 40 cycles of $95^{\circ} \mathrm{C}$ for $15 \mathrm{sec}$ alternating with $60^{\circ} \mathrm{C}$ for $1 \mathrm{~min}$ each. rtPCR analysis was similar to our previous studies ${ }^{14-16}$. Values for RNA abundance were normalized for each gene with respect to the endogenous control in that sample ( $\beta$-Actin), mean values for fold changes were calculated for each gene, and statistical testing was performed with the unpaired t-test (two-tailed).

\section{Results}

There were 54 genes with significantly increased expression and 43 genes with significantly reduced expression in diabetic compared with normal diaphragm, using the cutoff of at least a \pm 1.5 -fold changed expression in addition to consistent present calls by Affymetrix software and statistical significance by BAM. Using the same criteria, there were 50 genes with significantly increased expression and 52 genes with significantly reduced expression in diabetic compared to normal sternohyoid. A complete list of these genes, including mean fold change values for each gene, is provided in Additional file 1 (for online publication only). Classification of genes by Gene Ontology (GO) groups and statistical testing of over-representation among GO groups was done separately for each muscle for the genes with significantly changed expression.

Among the genes with at least 1.5-fold changed expression in diabetic diaphragm, assignment to GO groups was possible for 55 using the biological function classification, 61 using the molecular function classification, and 69 using the cellular constituent classification. In the diabetic sternohyoid, assignment to GO groups was possible for 66 using the biological function classification, 45 using the molecular function classification, and 58 using the cellular constituent classification. The GO terms with over-representation among these genes in the diaphragm and sternohyoid are indicated in Table 1.
The identified GO groups varied considerably with respect to number of constituent genes (ranging from 2 to 71) and degree of specificity (e.g., from specific terms such as fatty acid transport and glycerol-3-phosphate dehydrogenase activity to general terms such as cell and binding). The more specific GO groups were chosen for further analysis; in many instances there were clusters of closely related GO groups that were considered together (Table 2). Themes common to both muscles were lipid metabolism, carbohydrate metabolism, muscle contraction, ion transport and collagen. Themes present in only diaphragm were blood circulation and oxidoreductase activity. Themes present in only sternohyoid were immune \& inflammation and response to stress \& wounding.

The genes in both the diaphragm and sternohyoid that were classified in either lipid or carbohydrate metabolism GO groups, as well as the direction and magnitude of their changed expression, are listed in Table 3. In the diaphragm there were 9 genes involved in lipid metabolism (6 increased/3 decreased) and 7 genes involved in carbohydrate metabolism (1 increased/6 decreased). In the sternohyoid, there were 10 genes involved in lipid metabolism (7 increased/3 decreased) and 2 genes involved in carbohydrate metabolism ( 0 increased/2 decreased). With respect to specific genes, there were only 3 genes that had changed expression in both diaphragm and sternohyoid in response to diabetes. Carnitine O-octanoyltransferase (Crot), which plays a role in fatty acid transport, was increased in both muscles. Glycerol-3-phosphate dehydrogenase 2 (Gpd2), a carbohydrate metabolism gene which is involved in gluconeogenesis, and Acyl-CoA synthetase (Acsl6), a major enzyme in fatty acid metabolism gene, were decreased in both tissues. For both muscles together, lipid metabolism gene expression was increased more than decreased (total 13 vs. 6 genes). On the other hand, for carbohydrate metabolism, there were more genes that had decreased expression than those that had increased expression (total 8 vs. 1 genes).

There were 5 muscle contraction genes with significantly changed expression in the diaphragm (4 increased/ 1 decreased) and 6 with significantly changed expression in the sternohyoid ( 4 increased/2 decreased) with diabetes (Table 3). Of note is that myosin binding protein $\mathrm{H}$ (Mybph) and calsequestrin 2 (Casq2) were increased in both muscles, while none of the other muscle contraction genes with changed expression were in common. For both muscles together muscle contraction gene expression was increased more than decreased (total 9 vs. 3 genes).

Of the 20 genes from the ion transport GO groups in the diaphragm with changed expression due to diabetes, 9 are involved in calcium transport (Table 3). Five calcium genes were increased (Myl6b, Casq2, Itga7, Cacnb2 and $\mathrm{Sln}$ ) whereas four of the calcium genes were decreased 
Table 1 Statistically significant over-represented Gene Ontology (GO) terms to which genes with changed expression in diaphragm and sternohyoid of diabetic animals were assigned

\section{DIAPHRAGM}

\begin{tabular}{|c|c|c|c|}
\hline GO classification & GO group & \# genes & $P$ value \\
\hline \multicolumn{4}{|l|}{ Biological process } \\
\hline & Transport & 27 & 0.000089 \\
\hline & Establishment of localization & 27 & 0.00020 \\
\hline & Monocarboxylic acid metabolic process & 8 & 0.00035 \\
\hline & Localization & 29 & 0.00050 \\
\hline & Monosaccharide biosynthetic process & 4 & 0.00067 \\
\hline & Alcohol biosynthetic process & 4 & 0.00071 \\
\hline & Ion transport & 12 & 0.0015 \\
\hline & Alcohol metabolic process & 8 & 0.0018 \\
\hline & Hexose metabolic process & 6 & 0.0036 \\
\hline & Monosaccharide metabolic process & 6 & 0.0037 \\
\hline & Carboxylic acid metabolic process & 9 & 0.0069 \\
\hline & Inorganic anion transport & 5 & 0.0072 \\
\hline & Organic acid metabolic process & 9 & 0.0073 \\
\hline & Regulation of ion transport & 3 & 0.014 \\
\hline & Striated muscle contraction & 3 & 0.014 \\
\hline & Anion transport & 5 & 0.015 \\
\hline & Carbohydrate biosynthetic process & 4 & 0.016 \\
\hline & Blood circulation & 5 & 0.016 \\
\hline & Circulatory system process & 5 & 0.017 \\
\hline & Regulation of biological process & 28 & 0.018 \\
\hline & Lipid metabolic process & 9 & 0.019 \\
\hline & Heart development & 4 & 0.022 \\
\hline & Cardiac muscle development & 2 & 0.027 \\
\hline & Cellular carbohydrate metabolic process & 6 & 0.034 \\
\hline & Peptide transport & 3 & 0.036 \\
\hline & Carbohydrate metabolic process & 7 & 0.040 \\
\hline & Circadian rhythm & 3 & 0.040 \\
\hline & Multicellular organismal development & 18 & 0.042 \\
\hline & Regulation of multicellular organismal process & 6 & 0.044 \\
\hline & Developmental process & 23 & 0.045 \\
\hline & Regulation of transport & 4 & 0.046 \\
\hline & Regulation of the force of heart contraction & 2 & 0.047 \\
\hline & Long-chain fatty acid transport & 2 & 0.048 \\
\hline \multicolumn{4}{|c|}{ Cellular constituent } \\
\hline & Cytoplasm & 42 & 0.0000080 \\
\hline & Cytoplasmic part & 30 & 0.0014 \\
\hline & Fibrillar collagen & 3 & 0.0015 \\
\hline & Sarcoplasmic reticulum & 3 & 0.0047 \\
\hline & Intracellular part & 50 & 0.0048 \\
\hline & Sarcoplasm & 3 & 0.0065 \\
\hline & Sarcomere & 4 & 0.0066 \\
\hline & Endosome & 5 & 0.0066 \\
\hline & Plasma membrane & 20 & 0.0072 \\
\hline & Endoplasmic reticulum & 10 & 0.0097 \\
\hline
\end{tabular}


Table 1 Statistically significant over-represented Gene Ontology (GO) terms to which genes with changed expression in diaphragm and sternohyoid of diabetic animals were assigned (Continued)

\begin{tabular}{|c|c|c|c|}
\hline & Myofibril & 4 & 0.010 \\
\hline & Contractile fiber part & 4 & 0.010 \\
\hline & Intracellular & 52 & 0.011 \\
\hline & Collagen type I & 2 & 0.013 \\
\hline & Contractile fiber & 4 & 0.014 \\
\hline & Collagen & 3 & 0.018 \\
\hline & Smooth endoplasmic reticulum & 2 & 0.032 \\
\hline & Cell part & 71 & 0.039 \\
\hline & Cell & 71 & 0.039 \\
\hline \multicolumn{4}{|c|}{ Molecular function } \\
\hline & Protein binding & 39 & 0.0034 \\
\hline & Substrate specific channel activity & 6 & 0.018 \\
\hline & Calcium ion binding & 9 & 0.024 \\
\hline & Structural constituent of bone & 2 & 0.026 \\
\hline & Passive transmembrane transporter activity & 6 & 0.030 \\
\hline & Transporter activity & 13 & 0.031 \\
\hline & Channel activity & 6 & 0.031 \\
\hline & Auxiliary transport protein activity & 3 & 0.032 \\
\hline & Substrate-specific transporter activity & 11 & 0.033 \\
\hline & Oxidoreductase activity & 10 & 0.035 \\
\hline & Binding & 58 & 0.039 \\
\hline & Transmembrane transporter activity & 10 & 0.044 \\
\hline \multicolumn{4}{|l|}{ STERNOHYOID } \\
\hline GO classification & GO group & \# genes & $P$ value \\
\hline \multicolumn{4}{|l|}{ Biological process } \\
\hline & Regulation of multicellular organismal process & 12 & 0.0000012 \\
\hline & Humoral immune response & 6 & 0.0000075 \\
\hline & Complement activation & 5 & 0.000014 \\
\hline & Activation of plasma proteins during acute inflammatory response & 5 & 0.000016 \\
\hline & Acute inflammatory response & 6 & 0.000027 \\
\hline & Regulation of immune response & 6 & 0.000027 \\
\hline & Regulation of immune system process & 6 & 0.000036 \\
\hline & Activation of immune response & 5 & 0.000070 \\
\hline & Immune effector process & 6 & 0.000076 \\
\hline & Response to stress & 17 & 0.000096 \\
\hline & Monocarboxylic acid metabolic process & 9 & 0.00010 \\
\hline & Positive regulation of immune response & 5 & 0.00013 \\
\hline & Positive regulation of immune system process & 5 & 0.00016 \\
\hline & Carboxylic acid metabolic process & 12 & 0.00021 \\
\hline & Innate immune response & 5 & 0.00025 \\
\hline & Organic acid metabolic process & 12 & 0.00078 \\
\hline & Positive regulation of multicellular organismal process & 5 & 0.00091 \\
\hline & Long-chain fatty acid transport & 3 & 0.0012 \\
\hline & Muscle contraction & 6 & 0.0015 \\
\hline & Muscle system process & 6 & 0.0017 \\
\hline & Fatty acid transport & 3 & 0.0021 \\
\hline & Regulation of muscle contraction & 4 & 0.0022 \\
\hline
\end{tabular}


Table 1 Statistically significant over-represented Gene Ontology (GO) terms to which genes with changed expression in diaphragm and sternohyoid of diabetic animals were assigned (Continued)

\begin{tabular}{|c|c|c|c|}
\hline & Response to hormone stimulus & 6 & 0.0028 \\
\hline & Fatty acid metabolic process & 6 & 0.0030 \\
\hline & B cell mediated immunity & 4 & 0.0032 \\
\hline & Immune response & 9 & 0.0033 \\
\hline & Anion transport & 6 & 0.0037 \\
\hline & Lymphocyte mediated immunity & 4 & 0.0048 \\
\hline & $\begin{array}{l}\text { Adaptive immune response based on somatic recombination of immune receptors built from } \\
\text { immunoglobulin superfamily domains }\end{array}$ & 4 & 0.0057 \\
\hline & Adaptive immune response & 4 & 0.0062 \\
\hline & Humoral immune response mediated by circulating immunoglobulin & 3 & 0.0064 \\
\hline & Complement activation-classical pathway & 3 & 0.0064 \\
\hline & Defense response & 8 & 0.0067 \\
\hline & Leukocyte mediated immunity & 4 & 0.0071 \\
\hline & Response to biotic stimulus & 6 & 0.0074 \\
\hline & Lipid transport & 4 & 0.0077 \\
\hline & Inflammatory response & 6 & 0.0082 \\
\hline & Positive regulation of biological process & 13 & 0.0082 \\
\hline & Response to external stimulus & 10 & 0.0084 \\
\hline & Ion transport & 11 & 0.0089 \\
\hline & Inorganic anion transport & 5 & 0.010 \\
\hline & Cellular lipid metabolic process & 9 & 0.010 \\
\hline & Response to unfolded protein & 4 & 0.011 \\
\hline & Response to protein stimulus & 4 & 0.011 \\
\hline & Lipid metabolic process & 10 & 0.012 \\
\hline & Immune system process & 10 & 0.013 \\
\hline & Metabolic process & 53 & 0.015 \\
\hline & Response to steroid hormone stimulus & 4 & 0.022 \\
\hline & Response to wounding & 7 & 0.023 \\
\hline & Response to endogenous stimulus & 7 & 0.028 \\
\hline & Response to corticosteroid stimulus & 3 & 0.029 \\
\hline & Regulation of Wnt receptor signaling pathway & 3 & 0.030 \\
\hline & Response to peptide hormone stimulus & 3 & 0.037 \\
\hline & Regulation of biological process & 28 & 0.038 \\
\hline & Cellular metabolic process & 45 & 0.049 \\
\hline \multicolumn{4}{|l|}{ Cellular constituent } \\
\hline & Cytoplasm & 45 & $9.2 \mathrm{E}-07$ \\
\hline & Extracellular region part & 25 & 0.000068 \\
\hline & Proteinaceous extracellular matrix & 9 & 0.000087 \\
\hline & Extracellular matrix & 9 & 0.00010 \\
\hline & Extracellular region & 25 & 0.00017 \\
\hline & Extracellular space & 23 & 0.00030 \\
\hline & Collagen & 4 & 0.0013 \\
\hline & Cytoplasmic part & 31 & 0.00140 \\
\hline & Fibrillar collagen & 3 & 0.0016 \\
\hline & Extracellular matrix part & 5 & 0.00230 \\
\hline & Intracellular part & 52 & 0.0040 \\
\hline & Endoplasmic reticulum & 10 & 0.0080 \\
\hline
\end{tabular}


Table 1 Statistically significant over-represented Gene Ontology (GO) terms to which genes with changed expression in diaphragm and sternohyoid of diabetic animals were assigned (Continued)

\begin{tabular}{lll}
\hline & & 54 \\
\hline Intracellular & 0.011 & 0.012 \\
\hline Complement component C1 complex & 0.012 \\
\hline Collagen type I & 2 & 0.018 \\
\hline Glycerol-3-phosphate dehydrogenase complex & 2 & 0.033 \\
\hline Organelle outer membrane & 3 & 0.034 \\
\hline Envelope & 0.036 \\
\hline Organelle envelope & 7 \\
\hline & & 7 \\
\hline Glutathione transferase activity & 0.00076 \\
\hline Catalytic activity & 0.00090 \\
\hline Calcium ion binding & 0.0033 \\
\hline Transferase activity- transferring alkyl or aryl (other than methyl) groups & 4 \\
\hline Glycerol-3-phosphate dehydrogenase activity & 12 \\
\hline Transferase activity & 4 \\
\hline Structural constituent of bone & 0.0042 \\
\hline Magnesium ion binding & 0.012 \\
\hline
\end{tabular}

(Pvalb, Pln, S100a3 and Gpd2). The other smaller groups of ion transport genes were sodium and/or potassium (3 genes), chloride (1 gene), water (1 gene) and zinc (1 gene) and several other miscellaneous groups. There were also 4 collagen genes listed in the ion GO groups. Of the 23 genes from the ion transport GO groups in the sternohyoid with diabetes-induced changed expression, 10 are involved in calcium transport (Table 3). Half of the calcium GO group genes increased (Casq2, S100a4, Mgl1, $\mathrm{C} 1 \mathrm{qb}$ and C1qa) while the other half decreased (Fstl1, Eef2k, Atp2b3, Myl6b and Gpd2). The other smaller groups of ion transport genes are sodium and/or potassium (3 genes), magnesium (2 genes), and several other miscellaneous groups. There were also 3 collagen genes listed in the ion GO group. Among specific genes, three had altered expression in both muscles: Casq2 was increased and Gpd2 was decreased in both tissues while Myl6b was increased in diaphragm and decreased in sternohyoid. Not including the collagen genes, the ion transport genes were equally divided between increasing and decreasing expression with diabetes in both muscles (total 19 vs. 17 genes, not including collagen).

The collagen GO groups in the diaphragm had 3 genes and the sternohyoid had 4 genes with altered expression by diabetes. Colla1 and Colla2 had changed expression in both tissues. For both muscles all collagen gene expression changes were exclusively decreased (total 7 vs. 0 ).

Two sets of GO groups were over-represented in the diaphragm but not the sternohyoid muscle (Table 3). The blood circulation GO groups had 2 genes with increased and 3 genes with decreased expression. The oxidoreductase activity GO group had 4 genes with increased and 6 genes with decreased expression.
Two other sets of GO groups were over-represented in the sternohyoid but not the diaphragm muscle (Table 3). The immune and inflammatory GO groups had more genes with increased than decreased expression (total 7 vs 3). Of note is that all 5 complement genes had increased expression. The response to stress and wounding GO groups had 10 genes with increased expression and 7 genes with decreased genes expression. A subset of these genes were also included in the immune and inflammatory GO groups, including the 5 complement components with increased expression. However there were 10 genes in the stress and wounding GO groups that were not included in the immune and inflammatory GO groups.

To confirm changes in gene expression in diaphragm and sternohyoid, high throughput RT-PCR was performed on a subset of genes. The results which confirmed gene expression microarray data are presented Table 4 . The direction of changes determined by PCR were in the same direction as that determined by expression arrays. There was a good and statistically significant correlation between the magnitude of altered expression measured by gene expression array and that measured by RT-PCR for these genes (Figure 1).

\section{Discussion}

\section{Lipid and carbohydrate metabolism}

The pattern of carbohydrate and lipid substrate use is regulated closely to meet the metabolic demands of muscles at rest and during exercise and furthermore plays important modulatory roles in the pathophysiology of disease states such as diabetes. There is extensive biochemical literature indicating that diabetes results in a shift in cellular energetics away from carbohydrate and 
Table 2 Specific Gene Ontology groups which were examined in more detail to which genes with changed expression in diaphragm and sternohyoid of diabetic animals were assigned

\begin{tabular}{|c|c|c|c|c|}
\hline GO group category \& specific GO term & Diaphragm \# genes & $P$ value & Sternohyoid \# genes & $P$ value \\
\hline \multicolumn{5}{|l|}{ Metbolism - Lipid } \\
\hline Lipid metabolic process & 9 & 0.019 & 10 & 0.012 \\
\hline Long-chain fatty acid transport & 2 & 0.048 & 3 & 0.0012 \\
\hline Cellular lipid metabolic process & & & 9 & 0.010 \\
\hline Fatty acid metabolic process & & & 6 & 0.0030 \\
\hline Lipid transport & & & 4 & 0.0077 \\
\hline Fatty acid transport & & & 3 & 0.0021 \\
\hline
\end{tabular}

\section{Metabolism - Carbohydrate}

\begin{tabular}{lll}
\hline Carbohydrate metabolic process & 7 & 0.040 \\
\hline Monosaccharide metabolic process & 6 & 0.0037 \\
\hline Hexose metabolic process & 6 & 0.0036 \\
\hline Cellular carbohydrate metabolic process & 6 & 0.034 \\
\hline Carbohydrate biosynthetic process & 4 & 0.016 \\
\hline Glycerol-3-phosphate dehydrogenase complex & &
\end{tabular}

Glycerol-3-phosphate dehydrogenase complex

Glycerol-3-phosphate dehydrogenase activity

\section{Muscle contraction}

\begin{tabular}{lll}
\hline Sarcomere & 4 & 0.0066 \\
\hline Myofibril & 4 & 0.010 \\
\hline Contractile fiber part & 4 & 0.010 \\
\hline Contractile fiber & 4 & 0.014 \\
\hline Striated muscle contraction & 3 & 0.014 \\
\hline
\end{tabular}

Muscle system process

0.014

Muscle contraction

Regulation of muscle contraction

lon transport

\begin{tabular}{|c|c|c|c|c|}
\hline Ion transport & 12 & 0.0015 & 11 & 0.0089 \\
\hline Calcium ion binding & 9 & 0.024 & 12 & 0.0033 \\
\hline Inorganic anion transport & 5 & 0.0072 & 5 & 0.010 \\
\hline Anion transport & 5 & 0.015 & 6 & 0.0037 \\
\hline Regulation of ion transport & 3 & 0.014 & & \\
\hline Channel activity & 6 & 0.031 & & \\
\hline Magnesium ion binding & & & 5 & 0.037 \\
\hline \multicolumn{5}{|l|}{ Collagen } \\
\hline Fibrillar collagen & 3 & 0.0015 & 3 & 0.0016 \\
\hline Collagen & 3 & 0.018 & 4 & 0.0012 \\
\hline Collagen type I & 2 & 0.013 & 2 & 0.012 \\
\hline \multicolumn{5}{|l|}{ Blood circulation } \\
\hline Blood circulation & 5 & 0.016 & & \\
\hline Circulatory system process & 5 & 0.017 & & \\
\hline \multicolumn{5}{|l|}{ Oxidoreductase activity } \\
\hline Oxidoreductase activity & 10 & 0.035 & & \\
\hline \multicolumn{5}{|l|}{ Immune \& inflammatory } \\
\hline Immune system process & & & 10 & 0.013 \\
\hline Immune response & & & 9 & 0.0033 \\
\hline Defense response & & & 8 & 0.0067 \\
\hline Immune effector process & & & 6 & 0.000076 \\
\hline
\end{tabular}


Table 2 Specific Gene Ontology groups which were examined in more detail to which genes with changed expression in diaphragm and sternohyoid of diabetic animals were assigned (Continued)

\begin{tabular}{|c|c|c|}
\hline Acute inflammatory response & 6 & 0.000027 \\
\hline Regulation of immune system process & 6 & 0.000036 \\
\hline Inflammatory response & 6 & 0.0082 \\
\hline Humoral immune response & 6 & $7.5 \mathrm{E}-06$ \\
\hline Regulation of immune response & 6 & 0.000027 \\
\hline Activation of immune response & 5 & 0.000070 \\
\hline Positive regulation of immune system process & 5 & 0.00016 \\
\hline Complement activation & 5 & 0.000014 \\
\hline Positive regulation of immune response & 5 & 0.00013 \\
\hline Innate immune response & 5 & 0.00025 \\
\hline Adaptive immune response & 4 & 0.0062 \\
\hline Leukocyte mediated immunity & 4 & 0.0071 \\
\hline Lymphocyte mediated immunity & 4 & 0.0048 \\
\hline Adaptive immune response & 4 & 0.0057 \\
\hline B cell mediated immunity & 4 & 0.0032 \\
\hline Humoral immune response immunoglobulin & 3 & 0.0064 \\
\hline Complement activation-classical pathway & 3 & 0.0064 \\
\hline Complement component C1 complex & 2 & 0.012 \\
\hline \multicolumn{3}{|l|}{ Response to stress \& wounding } \\
\hline Response to stress & 17 & 0.000096 \\
\hline Response to wounding & 7 & 0.023 \\
\hline
\end{tabular}

towards lipid metabolism. Diabetic diaphragm has reduced uptake and phosphorylation of glucose, phosphorylation of fructose-6-phosphate, glycoysis, oxidation of pyruvate and acetate, uptake of acetoacete, production of glycogen, the proportion of the active complex of pyruvate dehydrogenase, and activites of hexokinase, phosphorylase and phosphofructokinase [20-27]. In addition, diabetic diaphragm has increased fat metabolism, uptake and oxidation of free fatty acids, output of glycerol, capacity for mobilization of intracellular lipids and intracellular concentrations of triglycerides, free fatty acid and longchain fatty acyl-CoA [27-30]. In type I diabetic rat heart glucose uptake and oxidation decreases, while fatty acid metabolism increases, indicating that diabetes shifts the pattern of cardiac energy metabolism in the same direction as the diaphragm [29,31]. Gerber et al. [32] has previously found that long chain fatty acids are the major energy source in streptozotocin-induced type I diabetic cardiac muscle with their beta-oxidation in mitochondria generating nearly $70 \%$ of the ATP. The gene expression changes which contribute to the carbohydrate to lipid metabolic shift have only been partially elucidated. In streptozotocin-induced diabetic rat diaphragm (a type 1 diabetes model), we found a small increase in expression of genes involved in lipid metabolism and a large decrease in expression of genes involved in carbohydrate metabolism, indicating that the gene expression contribution to the carbohydrate to lipid metabolic shift is directed most strongly at changes in carbohydrate metabolism [12] In contrast, type 1 diabetic rat heart has no significant change in carbohydrate gene expression but substantially augmented gene expression related to lipid metabolism [14]. The findings of the present study indicate that in diaphragm and sternohyoid muscles type 2 diabetes produces a similar overall shift favoring carbohydrate over lipid metabolism gene expression that was seen in type 1 diabetic rat diaphragm. However, data from the current and previous studies indicate that there are considerable differences between type 1 and type 2 diabetes (Tables 5 and 6), as well as between diaphragm and sternohyoid, in the number of genes with changed expression, the magnitude of the expression changes, and in the identity of the specific genes involved.

In the present study there were two metabolism genes with decreased expression in both the diaphragm and sternohyoid. The first gene was acyl-CoA synthetase longchain family member 6 (Acsl6) which catalyzes the ligation of long chain fatty acids with coenzyme A to produce long chain acyl-CoAs (Figure 2). This gene also had decreased expression in streptozotocin-induced diabetic diaphragm [12] and heart [33]. Acetyl-CoA is converted to malonylCoA which in turn inhibits CTP1 and the transport of fatty acid into the cell [34]. The second metabolism gene with decreased expression in both muscles was thyroid 
Table 3 Genes with changed expression in diabetic diaphragm and sternohyoid that were assigned to specific statistically over-represented Gene Ontology (GO) terms

\section{DIAPHRAGM}

\begin{tabular}{|c|c|c|}
\hline Gene title & Gene symbol & $F C$ \\
\hline \multicolumn{3}{|l|}{ ipid metabolism } \\
\hline Protein kinase, AMP-activated, alpha 1 catalytic subunit & Prkaa1 & 2.2 \\
\hline Cell death-inducing DNA fragmentation factor & Cidea & 2.2 \\
\hline Diazepam binding inhibitor & Dbi & 1.7 \\
\hline Carnitine O-octanoyltransferase & Crot & 1.6 \\
\hline Adipose differentiation related protein & Adfp & 1.6 \\
\hline Low density lipoprotein-related protein 1 (alpha-2-macroglobulin receptor) & Lrp1 & 1.5 \\
\hline Acyl-CoA synthetase long-chain family member 6 & Acsl6 & -1.7 \\
\hline Thyroid hormone responsive & Thrsp & -2.1 \\
\hline Transmembrane 7 superfamily member 2 & Tm7sf2 & -2.5 \\
\hline \multicolumn{3}{|l|}{ arbohydrate metabolism } \\
\hline Protein kinase, AMP-activated, alpha 1 catalytic subunit & Prkaa1 & 2.2 \\
\hline UDP-glucose pyrophosphorylase 2 & Ugp2 & -1.5 \\
\hline Solute carrier family 2 (facilitated glucose transporter), member 4 & Slc2a4 & -1.5 \\
\hline Coenzyme Q7 homolog, ubiquinone (yeast) & Coq7 & -1.6 \\
\hline 6-phosphofructo-2-kinase/fructose-2,6-biphosphatase 1 & Pfkfb1 & -1.7 \\
\hline Glycerol-3-phosphate dehydrogenase 2, mitochondrial & Gpd2 & -1.7 \\
\hline Dicarbonyl L-xylulose reductase & Dcxr & -2.0 \\
\hline \multicolumn{3}{|l|}{ Muscle contraction } \\
\hline Cysteine and glycine-rich protein 3 & Csrp3 & 4.2 \\
\hline Myosin binding protein $\mathrm{H}$ & Mybph & 3.0 \\
\hline PDZ and LIM domain 3 & Pdlim3 & 1.6 \\
\hline Calsequestrin 2 (cardiac muscle) & Casq2 & 1.5 \\
\hline Myosin, heavy chain 4, skeletal muscle & Myh4 & -3.6 \\
\hline on transport & & \\
\hline
\end{tabular}

\begin{tabular}{|c|c|c|}
\hline Myosin, light chain 6B, alkali, smooth muscle and non-muscle & Myl6b & 6.8 \\
\hline Calcium channel, voltage-dependent, beta 2 subunit & Cacnb2 & 1.6 \\
\hline Sarcolipin & $\operatorname{Sin}$ & 1.6 \\
\hline Calsequestrin 2 (cardiac muscle) & Casq2 & 1.5 \\
\hline Integrin alpha 7 & Itga7 & 1.5 \\
\hline Glycerol-3-phosphate dehydrogenase 2, mitochondrial & Gpd2 & -1.7 \\
\hline S100 calcium binding protein A3 & S100a3 & -1.7 \\
\hline Parvalbumin & Pvalb & -2.0 \\
\hline Phospholamban & Pln & -2.4 \\
\hline \multicolumn{3}{|l|}{ Sodium/Potassium channels } \\
\hline Sodium channel, voltage-gated, type III, beta & Scn3b & 2.2 \\
\hline Potassium large conductance calcium-activated channel subfamily M, alpha member 1 & Kcnma1 & 1.5 \\
\hline FXYD domain-containing ion transport regulator 7 & Fxyd7 & -1.7 \\
\hline \multicolumn{3}{|l|}{ Other channels } \\
\hline Low density lipoprotein-related protein 1 (alpha-2-macroglobulin receptor) & Lrp1 & 1.5 \\
\hline Solute carrier family 30 (zinc transporter), member 4 & Slc30a4 & 1.5 \\
\hline Aquaporin 1 & Aqp1 & -1.5 \\
\hline Chloride channel 4-2 & Clcn4-2 & -1.8 \\
\hline
\end{tabular}


Table 3 Genes with changed expression in diabetic diaphragm and sternohyoid that were assigned to specific statistically over-represented Gene Ontology (GO) terms (Continued)

\begin{tabular}{|c|c|c|}
\hline Collagen & & \\
\hline Collagen, type I, alpha 2 & Col1a2 & -1.6 \\
\hline Collagen, type III, alpha 1 & Col3a1 & -1.7 \\
\hline Collagen, type I, alpha 1 & Col1a1 & -2.0 \\
\hline Ficolin (collagen/fibrinogen domain containing) 1 & Fen1 & -2.1 \\
\hline \multicolumn{3}{|l|}{ Collagen } \\
\hline Collagen, type I, alpha 2 & Col1a2 & -1.6 \\
\hline Collagen, type III, alpha 1 & Col3a1 & -1.7 \\
\hline Collagen, type I, alpha 1 & Col1a1 & -2.0 \\
\hline \multicolumn{3}{|l|}{ Blood circulation } \\
\hline Cysteine and glycine-rich protein 3 & Csrp3 & 4.2 \\
\hline Potassium large conductance calcium-activated channel subfamily M, alpha member 1 & Kcnma1 & 1.5 \\
\hline Collagen, type III, alpha 1 & Col3a1 & -1.7 \\
\hline Apelin & Apln & -2.2 \\
\hline Phospholamban & Pln & -2.4 \\
\hline \multicolumn{3}{|l|}{ Oxidoreductase activity } \\
\hline 2,4-dienoyl CoA reductase 1, mitochondrial & Decr1 & 2.0 \\
\hline IMP (inosine monophosphate) dehydrogenase 2 & Impdh2 & 1.6 \\
\hline Potassium large conductance calcium-activated channel subfamily M, alpha member 1 & Kcnma1 & 1.5 \\
\hline Solute carrier family 30 (zinc transporter), member 4 & Slc30a4 & 1.5 \\
\hline Coenzyme Q7 homolog, ubiquinone (yeast) & Coq7 & -1.6 \\
\hline Glycerol-3-phosphate dehydrogenase 2, mitochondrial & Gpd2 & -1.7 \\
\hline S100 calcium binding protein A3 & S100a3 & -1.7 \\
\hline Dicarbonyl L-xylulose reductase & Dcxr & -2.0 \\
\hline Phytanoyl-CoA dioxygenase domain containing 1 & Phyhd1 & -2.1 \\
\hline Transmembrane 7 superfamily member 2 & Tm7sf2 & -2.5 \\
\hline \multicolumn{3}{|l|}{ STERNOHYOID } \\
\hline Gene title & Gene Symbol & $F C$ \\
\hline \multicolumn{3}{|l|}{ Lipid metabolism } \\
\hline Acyl-CoA thioesterase 2 & Acot2 & 2.4 \\
\hline Nudix (nucleoside diphosphate linked moiety X)-type motif 4 & Nudt4 & 2.1 \\
\hline Retinol saturase (all trans retinol 13,14 reductase) & Retsat & 1.9 \\
\hline Carnitine palmitoyltransferase $1 \mathrm{~b}$, muscle & Cpt1b & 1.7 \\
\hline Carnitine O-octanoyltransferase & Crot & 1.6 \\
\hline Carnitine palmitoyltransferase 2 & Cpt2 & 1.5 \\
\hline Solute carrier family 27 (fatty acid transporter), member 1 & Slc27a1 & 1.5 \\
\hline Acyl-CoA synthetase long-chain family member 6 & Acsl6 & -1.6 \\
\hline Thyroid hormone responsive & Thrsp & -2.1 \\
\hline Sterol regulatory element binding transcription factor 1 & Srebf1 & -2.4 \\
\hline \multicolumn{3}{|l|}{ Carbohydrate metabolism } \\
\hline Glycerol-3-phosphate dehydrogenase 1 (soluble) & Gpd1 & -1.6 \\
\hline Glycerol-3-phosphate dehydrogenase 2, mitochondrial & Gpd2 & -1.8 \\
\hline \multicolumn{3}{|l|}{ Muscle contraction } \\
\hline Myosin binding protein $\mathrm{H}$ & Mybph & 8.6 \\
\hline Complement component $4 \mathrm{a}$ & $\mathrm{C} 4 \mathrm{a}$ & 2.0 \\
\hline Calsequestrin 2 (cardiac muscle) & Casq2 & 2.0 \\
\hline Cholinergic receptor, nicotinic, delta & Chrnd & 1.9 \\
\hline
\end{tabular}


Table 3 Genes with changed expression in diabetic diaphragm and sternohyoid that were assigned to specific statistically over-represented Gene Ontology (GO) terms (Continued)

\begin{tabular}{|c|c|c|}
\hline Heat shock protein, alpha-crystallin-related, B6 & Hspb6 & -1.6 \\
\hline Guanidinoacetate N-methyltransferase & Gamt & -1.6 \\
\hline \multicolumn{3}{|l|}{ Ion transport } \\
\hline \multicolumn{3}{|l|}{ Calcium channel } \\
\hline S100 calcium-binding protein A4 & S100a4 & 1.9 \\
\hline Complement component 1, q subcomponent, beta polypeptide & $\mathrm{C} 1 \mathrm{qb}$ & 1.7 \\
\hline Complement component 1, q subcomponent, alpha polypeptide & C1qa & 1.6 \\
\hline Macrophage galactose N-acetyl-galactosamine specific lectin 1 & Mgl1 & 1.5 \\
\hline Calsequestrin 2 (cardiac muscle) & Casq2 & 1.5 \\
\hline Follistatin-like 1 & Fstl1 & -1.5 \\
\hline Glycerol-3-phosphate dehydrogenase 2, mitochondrial & Gpd2 & -1.7 \\
\hline Eukaryotic elongation factor-2 kinase & Eef2k & -2.0 \\
\hline ATPase, Ca++ transporting, plasma membrane 3, (AKA PMCA2) & Atp2b3 & -2.1 \\
\hline Myosin, light chain 6B, alkali, smooth muscle and non-muscle & Myl6b & -2.5 \\
\hline \multicolumn{3}{|l|}{ Sodium/Potassium channels } \\
\hline FXYD domain-containing ion transport regulator 2 & Fxyd2 & 1.6 \\
\hline Potassium large conductance calcium-activated channel subfamily M, alpha member 1 & Kcnmal & 1.5 \\
\hline ATPase, $\mathrm{Na}+/ \mathrm{K}+$ transporting, beta 2 polypeptide & Atp1b2 & -1.6 \\
\hline \multicolumn{3}{|l|}{ Magnesium } \\
\hline Inositol (myo)-1(or 4)-monophosphatase 2 & Impa2 & 1.8 \\
\hline Acyl-CoA synthetase long-chain family member 6 & Acsl6 & -1.6 \\
\hline \multicolumn{3}{|l|}{ Other channels } \\
\hline Latent transforming growth factor beta binding protein 1 & Ltbp1 & 2.0 \\
\hline Cholinergic receptor, nicotinic, delta & Chrnd & 1.9 \\
\hline 2,4-dienoyl CoA reductase 2, peroxisomal & Decr2 /// Rab11fip3 & -1.6 \\
\hline Solute carrier family 16, member 3 (monocarboxylic acid transporter 4) & Slc16a3 & -1.7 \\
\hline Amylase, alpha 1A (salivary) & Amyla & -1.7 \\
\hline \multicolumn{3}{|l|}{ Collagen } \\
\hline Collagen, type $V$, alpha 1 & Col5a1 & -1.8 \\
\hline Collagen, type I, alpha 1 & Col1a1 & -1.9 \\
\hline Collagen, type I, alpha 2 & Col1a2 & -2.2 \\
\hline \multicolumn{3}{|l|}{ Collagen } \\
\hline Collagen, type V, alpha 1 & Col5a1 & -1.8 \\
\hline Collagen, type XV, alpha 1 & Col15a1 & -1.9 \\
\hline Collagen, type I, alpha 1 & Col1a1 & -1.9 \\
\hline Collagen, type I, alpha 2 & Col1a2 & -2.2 \\
\hline \multicolumn{3}{|l|}{ Immune \& inflammatory } \\
\hline Cyclin-dependent kinase inhibitor 1A (p21, Cip1) & Cdkn1a & 2.4 \\
\hline Fc fragment of lgG, low affinity IIb, receptor (CD32) & Fcgr2b & 2.2 \\
\hline Complement component $4 a$ & $\mathrm{C} 4 \mathrm{a}$ & 2.0 \\
\hline Adipsin & Adn & 1.8 \\
\hline Complement component 1, q subcomponent, beta polypeptide & C1qb & 1.7 \\
\hline Complement component 1, q subcomponent, alpha polypeptide & C1qa & 1.6 \\
\hline Complement factor $\mathrm{H}$ & Cfh & 1.6 \\
\hline Dipeptidylpeptidase 4 & Dpp4 & -1.9 \\
\hline Myxovirus (influenza virus) resistance 1 & Mx1 & -1.9 \\
\hline Spondin 2, extracellular matrix protein & Spon2 & -2.0 \\
\hline
\end{tabular}


Table 3 Genes with changed expression in diabetic diaphragm and sternohyoid that were assigned to specific statistically over-represented Gene Ontology (GO) terms (Continued)

\begin{tabular}{|c|c|c|}
\hline \multicolumn{3}{|l|}{ Response to stress \& wounding } \\
\hline Cyclin-dependent kinase inhibitor 1A (p21, Cip1) & Cdkn1a & 2.4 \\
\hline Acyl-CoA thioesterase 2 & Acot2 & 2.4 \\
\hline Fc fragment of IgG, low affinity IIb, receptor (CD32) & Fcgr2b & 2.2 \\
\hline Complement component $4 a$ & $\mathrm{C} 4 \mathrm{a}$ & 2.0 \\
\hline Deleted in malignant brain tumors 1 & Dmbt1 & 1.9 \\
\hline Complement factor D (adipsin) & Adn & 1.8 \\
\hline Complement component 1, q subcomponent, beta polypeptide & $\mathrm{C} 1 \mathrm{qb}$ & 1.7 \\
\hline Potassium large conductance calcium-activated channel subfamily M, alpha member 1 & Kenma1 & 1.6 \\
\hline Complement component 1, q subcomponent, alpha polypeptide & C1qa & 1.6 \\
\hline Complement factor $\mathrm{H}$ & Cfh & 1.6 \\
\hline Epidermal growth factor receptor & Egfr & -1.5 \\
\hline SRY (sex determining region Y)-box 4 & Sox4 & -1.6 \\
\hline Serine (or cysteine) peptidase inhibitor, clade $\mathrm{H}$, member 1 & Serpinh1 & -1.6 \\
\hline Heat shock protein, alpha-crystallin-related, B6 & Hspb6 & -1.6 \\
\hline Collagen, type I, alpha 1 & Colla1 & -1.9 \\
\hline Heat shock protein 2 & Hspa2 & -2.0 \\
\hline Sterol regulatory element binding transcription factor 1 & Srebf1 & -2.4 \\
\hline
\end{tabular}

hormone responsive (Thrsp), which is believed to be involved in lipogenesis [35,36]. The diaphragm had decreased expression of transmembrane 7 superfamily member 2 (Tm7sf2) which is involved in cholesterol biosynthesis, [37] while the sternohyoid had a decrease in sterol regulatory element binding transcription factor 1 (Srebf1) which regulates the transcription of genes important for sterol biosynthesis. Srebf1 also had decreased expression in limb muscle of 12-week old type 2 diabetic rat [11].

There were several genes with increased expression in the lipid metabolism GO group that increased in previous studies of diabetes. 2,4-dienoyl CoA reductase 1 (Decr1) catalyzes the conversion of 2,4 dienoyl-CoA to cis- $\Delta^{3}$-enoyl-CoA and is involved in the mitochondrial long-chain fatty acid beta-oxidation pathway (Figure 2). In previous studies, Decr1 increased 5-fold in type 1 streptozotocin diabetic rat liver mitochondia [38], 2-fold in our previous studies in type 1 diabetic rat diaphragm [12] and heart [14], 2-fold in type 1 diabetic rat heart [39] and nearly four-fold in limb skeletal muscle of 12 week old type 2 diabetic rats [11]. Adipose differentiation related protein (Adfp) has increased expression in $\mathrm{db} / \mathrm{db}$ mouse kidney [40]. Cell death-inducing DNA fragmentation factor (Cidea), also increased in the diabetic diaphragm, may play a role in lipolysis, but its role is still not clearly defined. In previous studies Cidea-null mutants have been diabetes-resistant $[41,42]$. It is possible that Cidea functions by modulating fatty acid metabolism since the Cidea-null mutants had much lower concentrations of plasma FFA and triglycerides [42].

In the sternohyoid, four out of the six lipid metabolism genes with increased expression (Cpt1b, Cpt2, Acot2 and Slc27a1) are also involved directly in fatty acid transport and oxidation. Carnitine palmitoyltransferase (Cpt1b) catalyses the transfer of long chain fatty acids to carnitine for translocation across the mitochondrial inner membrane and then Cpt2 is an inner mitochondrial membrane protein that converts long chain acylcarnitine to long chain acyl-CoA (Figure 2). They are also increased in streptozotocin-induced diabetic rat heart [32]. Cpt1b has heterogeneous changes, depending on tissue type. Cpt1b expression is increased in human type 2 diabetic adipose tissue [43] and type 1 diabetic rat heart [39]. However, it is reduced in human type II vastus lateralis [43] and streptozotocin-induced diabetic rat liver [44]. Acyl-CoA thioesterase 2 (Acot 2 or Mte1), catalyzes the hydrolysis of fatty acyl-CoA molecules into nonesterified fatty acid anions and free CoA in the mitochondria and has increased expression in heart and soleus of streptozotocin-induced diabetic rats [45]. Slc27a1 is a fatty acid transporter, which increases fatty acid supply when its expression is increased, and therefore is thought to increase fatty acid metabolism [46].

There were only two genes that had significantly decreased expression levels in the sternohyoid carbohydrate metabolism GO group (Gpd1 and Gpd2). Gpd2 expression was also decreased in diaphragm muscle. Gpd1 and Gpd2 are glycerol-3-phosphate dehydrogenase genes that 
Table 4 Confirmatory results for changes in gene expression in diaphragm and sternhyoid measured by real-time PCR

\begin{tabular}{|c|c|c|c|}
\hline \multicolumn{4}{|c|}{ DIAPHRAGM } \\
\hline $\begin{array}{l}\text { Gene } \\
\text { symbol }\end{array}$ & $\begin{array}{l}\text { Fold change by } \\
\text { microarray }\end{array}$ & $\begin{array}{c}\text { Fold change } \\
\text { by } P C R\end{array}$ & $\begin{array}{l}P \text { value } \\
\text { by } P C R\end{array}$ \\
\hline Csrp3 & 4.2 & 7.6 & 0.022 \\
\hline Mybph & 3.0 & 4.6 & 0.0010 \\
\hline Decr1 & 2.0 & 3.9 & $<0.001$ \\
\hline $\operatorname{SIn}$ & 1.6 & 3.3 & 0.037 \\
\hline Dbi & 1.7 & 2.6 & 0.013 \\
\hline Adfp & 1.6 & 2.1 & $<0.001$ \\
\hline Kcnma1 & 1.5 & 2.1 & $<0.001$ \\
\hline Crot & 1.6 & 2.0 & $<0.001$ \\
\hline Lrp1 & 1.5 & 1.9 & 0.004 \\
\hline Prkaa1 & 2.2 & 1.8 & $<0.001$ \\
\hline Gpd2 & -1.7 & -1.2 & 0.010 \\
\hline Acsl6 & -1.7 & -1.4 & 0.0060 \\
\hline Pln & -2.4 & -1.9 & 0.017 \\
\hline Apln & -2.2 & -2.2 & $<0.001$ \\
\hline Myh4 & -3.6 & -4.8 & 0.01 \\
\hline \multicolumn{4}{|c|}{ STERNOHYOID } \\
\hline $\begin{array}{l}\text { Gene } \\
\text { symbol }\end{array}$ & $\begin{array}{c}\text { Fold change by } \\
\text { microarray }\end{array}$ & $\begin{array}{c}\text { Fold change } \\
\text { by } P C R\end{array}$ & $\begin{array}{l}P \text { value } \\
\text { by } P C R\end{array}$ \\
\hline Decr1 & 3.3 & 4.7 & $<0.001$ \\
\hline Cakn1a & 2.4 & 3.7 & 0.0090 \\
\hline Acot2 & 2.4 & 3.3 & 0.0060 \\
\hline Fcgr2b & 2.2 & 4.0 & $<0.001$ \\
\hline $\mathrm{C} 4 \mathrm{a}$ & 2.0 & 2.4 & $<0.001$ \\
\hline Adn & 1.8 & 2.5 & 0.0060 \\
\hline Cpt1b & 1.7 & 2.2 & 0.0050 \\
\hline Kcnma1 & 1.6 & 1.9 & 0.0030 \\
\hline Crot & 1.6 & 2.9 & 0.0020 \\
\hline C1qa & 1.6 & 2.0 & 0.038 \\
\hline Cfh & 1.6 & 1.7 & 0.0010 \\
\hline Cpt2 & 1.5 & 2.1 & 0.0040 \\
\hline Slc27a1 & 1.5 & 2.1 & 0.023 \\
\hline Acsl6 & -1.6 & -1.4 & 0.0020 \\
\hline
\end{tabular}

Fold changes $(\mathrm{FC})$ in gene expression are represented in the last column.

are important members of the glycerol phosphate shuttle which are involved in the interconversion of glycerol3-phosphate and dihydroxyacetone phosphate with concomitant reduction of FAD. Gpd2 also had decreased expression in the streptozotocin-induced diabetic rat heart [14] and diaphragm [12].

In addition to Gpd2, there were five other genes with decreased expression in the diaphragm that are involved in carbohydrate metabolism (Slc2a4, Ugp2, Dcxr, Pfkfb1, Coq7). Slc2a4, Glucose Transporter 4, is involved in transporting glucose across the membrane [47] and has diminished expression and function in type II diabetic rat heart [48] and slow muscle fibers and omental fat of type II diabetic patients [49,50]. Ugp2, UDP-glucose pyrophosphorylase 2 is essential for sucrose and polysaccharide synthesis [51] and has decreased expression in limb muscle of 12-week old type 2 diabetic rats [11]. The remaining 3 decreased diaphragm carbohydrate metabolism genes, Dcxr, Pfkfb1 and Coq7, were not significantly changed in any previous diabetes studies. Dicarbonyl L-xylulose reductase (Dcxr) functions in the metabolism of glucose [52]. 6-phosphofructo-2kinase (Pfkfb1) is a rate limiting enzyme of glycolysis [53-57] which catalyzes the synthesis and degradation of fructose 2,6-bisphosphate. Coq7, coenzyme Q7, is a component of the electron transport chain which generates energy in the form of ATP.

\section{Muscle contraction}

There has been a paucity of muscle contraction genes found to be altered due to diabetes in previous gene array studies. We are not aware of any muscle genes that were changed in the sternohyoid that have been found to be changed previously. However, the expression of cysteine and glycine-rich protein (Csrp3) gene increased in calf muscle in streptozotocin-induced diabetic mice, [58] similar to the diaphragm present study. This gene is thought to play a role in myogenesis. Mybph and Casq2 were the 2 genes that were increased in both muscles in the present study. Mybph is a skeletal muscle binding protein which binds myosin and is probably involved in the interaction with thick myofilaments in the A-band. Casq 2 is a calcium binding protein that stores calcium for muscle contraction.

\section{Ion channels and transport}

In our previous two studies of streptozotocin-induced type I diabetic heart and diaphragm gene expression we found decreased expression in 13 calcium binding genes in heart [14] and 10 calcium ion genes in the diaphragm [12].

Similar to the diabetic diaphragm in the present study, there was decreased expression of parvalbumin (Pvalb) in the nerve, [59] gastrocnemius [8] and diaphragm [12] of streptozotocin-induced type I diabetic rats. This protein binds two calcium ions and is involved in muscle relaxation. Previous studies have found conflicting results in levels of phospholamben (Pln) expression in diabetes. $\mathrm{Pln}$ is a key regulator of the sarcoplasmic reticulum ATPase and thus involved in calcium handling [60]. An increase in the mRNA and phospholamben protein levels is postulated to cause an increase in sarcoplasmic reticulum calcium reuptake inhibition [61]. In contrast to the current study, Zhong et al. [62] found a $31-60 \%$ increase in Pln in 4 and 6-week old streptozotocininduced type I diabetic rat heart [62]. There was one 


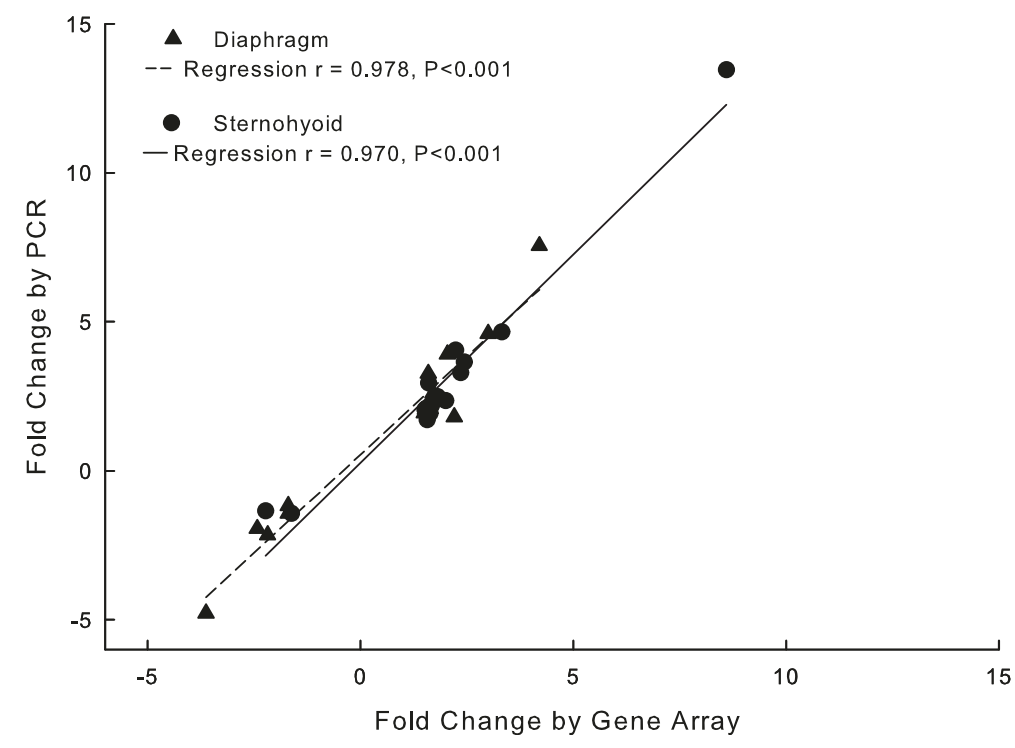

Figure 1 Relationship between fold changes in gene expression measured by gene expression microarray and real-time PCR.

previous study that found decreased Pln expression in streptozotocin-induced type I diabetic rat heart [63]. They also measured the amount of Pln phosphorylation by CaMK and PKA and found that to also be decreased and therefore postulated that because Pln phosphorylation inhibits the Pln inhibitory action, the decreased amount of Pln was still able to cause impaired Ca uptake. Glycerol3-phosphate dehydrogenase (Gpd2) enhances lipid metabolism by binding calcium. Expression of this protein was decreased in streptozotocin-induced diabetic rat heart and diaphragm, $[12,14]$ similar to the current study. The last decreased calcium binding gene in this group, S100 calcium binding protein $\mathrm{A} 3$ (S100a3), has not changed in any previous experiments with diabetes. The five increased calcium genes (Myl6b, Casq2, Itga7, Cacnb2 and Sln) have not had changed expression in previous diabetes studies. Their functions involve calcium binding and calcium channels. Sarcolipin (Sln) is also involved in sarcoplasmic reticulum calcium regulation similar to phospholamben, so it is possible that the increase in Sln expression could be a compensatory mechanism for the decrease in Pln.

In the diabetic sternohyoid, three of the five calcium channel genes with decreased expression (Fstl1, Atp2b3, Eef2k, Gpd2, Myl6b) were decreased in previous diabetes studies. Follistatin-like 1 (Fstl1) and glycerol-3-phosphate dehydrogenase (Gpd2) were decreased in streptozotocininduced type 1 diabetic heart [14]. Atp2b3 protein content was decreased in insulin-resistant Wistar rat islet plasma membranes [64]. Several eukaryotic translation initiation and elongation factors are decreased in streptozotocininduced diabetic rodent gastrocnemius muscle $[8,65]$, however until the present study eukaryotic elongation factor kinase (Eef2k) has not previously been significantly changed due to diabetes. Eef2k is completely dependent on calcium and calmodulin and provides a key link between cellular energy status and the inhibition of protein synthesis [66-68]. Myl6b has not been significantly changed in previous studies involving diabetes. Five calcium genes were increased in the sternohyoid (Casq2, S100a4, Mgl1, C1qb and C1qa). The S100a4 gene was upregulated in a previous study in the peripheral leukocytes of streptozotocin-induced diabetic rats [69], while the other 4 did not have changed expression levels due to diabetes.

There are several genes that were classified in the ion channel GO grouping in the diaphragm that are involved in other channels besides calcium ions. These genes are Fxyd7, Scn3b and Kcnma1 which are involved in sodium and potassium channels, Clcn4-2, which is a voltage-gated chloride channel protein, Aqp1, which is a water channel, and Slc30a4, which is a zinc transporter. Lrp1 is a transmembrane receptor which functions in the endocytosis of over 40 structurally and functionally distinct ligands [70,71]. Aquaporin 1 (Aqp1) is the only non-calcium ion gene that has previously been examined in diabetes, however with conflicting results. Baelde et al. [72] found an increase in Aqp1 in human type II diabetic kidney, while others found no changes in protein levels in kidneys of streptozotocin-induced diabetic mice [73] and streptozotocin-induced diabetic rats [74].

There are also several genes that were classified in the ion channel GO grouping in the sternohyoid that are involved in other ion channels besides calcium. These genes are Fxyd2, Atp1b2 and Kcnma1 which are involved in sodium and potassium channels, Impa2 and Acsl6, which are regulated by magnesium, Slc16a3, which transports 
Table 5 Specific Gene Ontology groups and number of genes which were examined in more detail in type II diabetic diaphragm and the corresponding changes in genes in type I diabetic diaphragm in a previous study (12)

\begin{tabular}{|c|c|}
\hline GO group category \& specific GO term & Diaphragm \\
\hline & Type II \\
\hline & \# genes \\
\hline \multicolumn{2}{|l|}{ Metbolism - Lipid } \\
\hline Lipid metabolic process & 9 \\
\hline Long-chain fatty acid transport & 2 \\
\hline \multicolumn{2}{|l|}{ Cellular lipid metabolic process } \\
\hline \multicolumn{2}{|l|}{ Fatty acid metabolic process } \\
\hline \multicolumn{2}{|l|}{ Lipid transport } \\
\hline Fatty acid transport & \\
\hline
\end{tabular}

\begin{tabular}{|c|c|c|c|c|}
\hline Carbohydrate metabolic process & 7 & 0.04 & 8 & 0.000061 \\
\hline Monosaccharide metabolic process & 6 & 0.0037 & 5 & 0.0059 \\
\hline Hexose metabolic process & 6 & 0.0036 & 5 & 0.0059 \\
\hline Cellular carbohydrate metabolic process & 6 & 0.034 & 5 & 0.005 \\
\hline Carbohydrate biosynthetic process & 4 & 0.016 & & \\
\hline \multicolumn{5}{|c|}{ Glycerol-3-phosphate dehydrogenase complex } \\
\hline \multicolumn{5}{|c|}{ Glycerol-3-phosphate dehydrogenase activity } \\
\hline \multicolumn{5}{|l|}{ Muscle contraction } \\
\hline Sarcomere & 4 & 0.0066 & & \\
\hline Myofibril & 4 & 0.01 & & \\
\hline Contractile fiber part & 4 & 0.01 & & \\
\hline Contractile fiber & 4 & 0.014 & & \\
\hline Striated muscle contraction & 3 & 0.014 & & \\
\hline \multicolumn{5}{|l|}{ Muscle system process } \\
\hline \multicolumn{5}{|l|}{ Muscle contraction } \\
\hline \multicolumn{5}{|l|}{ Regulation of muscle contraction } \\
\hline \multicolumn{5}{|l|}{ lon transport } \\
\hline Ion transport & 12 & 0.0015 & & \\
\hline Calcium ion binding & 9 & 0.024 & 10 & 0.00003 \\
\hline Inorganic anion transport & 5 & 0.0072 & & \\
\hline Anion transport & 5 & 0.015 & & \\
\hline Regulation of ion transport & 3 & 0.014 & & \\
\hline Channel activity & 6 & 0.031 & & \\
\hline \multicolumn{5}{|l|}{ Magnesium ion binding } \\
\hline \multicolumn{5}{|l|}{ Collagen } \\
\hline Fibrillar collagen & 3 & 0.0015 & 3 & 0.00033 \\
\hline Collagen & 3 & 0.018 & 4 & 0.00014 \\
\hline Collagen type I & 2 & 0.013 & & \\
\hline \multicolumn{5}{|l|}{ Blood circulation } \\
\hline Blood circulation & 5 & 0.016 & & \\
\hline Circulatory system process & 5 & 0.017 & & \\
\hline \multicolumn{5}{|l|}{ Oxidoreductase activity } \\
\hline Oxidoreductase activity & 10 & 0.035 & 8 & 0.024 \\
\hline
\end{tabular}


Table 6 Genes with changed expression in diaphragm of type II and type I (12) diabetic rats that were assigned to specific statistically over-represented gene ontology (GO) terms TYPE II DIAPHRAGM

\begin{tabular}{|c|c|c|}
\hline & Gene & Fold \\
\hline Oxidoreductase activity & Symbol & Change \\
\hline 2,4-dienoyl CoA reductase 1 , mitochondrial & Decr1 & 2 \\
\hline IMP (inosine monophosphate) dehydrogenase 2 & Impdh2 & 1.6 \\
\hline Potassium large conductance calcium-activated channel subfamily M, alpha member 1 & Kcnma1 & 1.5 \\
\hline Solute carrier family 30 (zinc transporter), member 4 & Slc30a4 & 1.5 \\
\hline Coenzyme Q7 homolog, ubiquinone (yeast) & Coq7 & -1.6 \\
\hline Glycerol-3-phosphate dehydrogenase 2, mitochondrial & Gpd2 & -1.7 \\
\hline S100 calcium binding protein A3 & S100a3 & -1.7 \\
\hline Dicarbonyl L-xylulose reductase & Dexr & -2 \\
\hline Phytanoyl-CoA dioxygenase domain containing 1 & Phyhd1 & -2.1 \\
\hline Transmembrane 7 superfamily member 2 & Tm7sf2 & -2.5 \\
\hline \multicolumn{3}{|l|}{ Carbohydrate metabolism } \\
\hline protein kinase, AMP-activated, alpha 1 catalytic subunit & Prkaa1 & 2.2 \\
\hline UDP-glucose pyrophosphorylase 2 & Ugp2 & -1.5 \\
\hline Solute carrier family 2 (facilitated glucose transporter), member 4 & Slc2a4 & -1.5 \\
\hline Coenzyme Q7 homolog, ubiquinone (yeast) & Coq7 & -1.6 \\
\hline 6-phosphofructo-2-kinase/fructose-2,6-biphosphatase 1 & Pfkfb1 & -1.7 \\
\hline Glycerol-3-phosphate dehydrogenase 2, mitochondrial & Gpd2 & -1.7 \\
\hline Dicarbonyl L-xylulose reductase & Dcxr & -2 \\
\hline \multicolumn{3}{|l|}{ Collagen } \\
\hline Collagen, type I, alpha 2 & Col1a2 & -1.6 \\
\hline Collagen, type III, alpha 1 & Col3a1 & -1.7 \\
\hline Collagen, type I, alpha 1 & Col1a1 & -2 \\
\hline Ficolin (collagen/fibrinogen domain containing) 1 & Fen1 & -2.1 \\
\hline \multicolumn{3}{|l|}{ TYPE I DIAPHRAGM } \\
\hline \multicolumn{3}{|l|}{ Oxidoreductase activity } \\
\hline Cytochrome P450, family 2, subfamily e, polypeptide 1 & Cyp2e1 & 6 \\
\hline Flavin containing monooxygenase 3 & Fmo3 & 2.9 \\
\hline Crystallin, lamda 1 & Cryl1 & 2.4 \\
\hline Lysyl oxidase & Lox & 2.3 \\
\hline Ceruloplasmin & $\mathrm{Cp}$ & 2.2 \\
\hline 2,4-dienoyl CoA reductase 1 , mitochondrial & Decr1 & 2.2 \\
\hline Aldehyde oxidase 1 & Aox1 & 2.1 \\
\hline P450 (cytochrome) oxidoreductase & Por & 2.1 \\
\hline \multicolumn{3}{|l|}{ Carbohydrate metabolism } \\
\hline Neuraminidase 2 & $\mathrm{Neu} 2$ & -8.5 \\
\hline Phosphofructokinase, liver, B-type & Pfkl & -3.7 \\
\hline Solute carrier family 37 (glycerol-6-phosphate transporter), member 4 & Slc37a4 & -2.5 \\
\hline Glycerol-3-phosphate dehydrogenase 2 & Gpd2 & -2.3 \\
\hline Amylase 1, salivary & Amy1 & -2.3 \\
\hline Phosphoglycerate mutase 2 & Pgam2 & -2.1 \\
\hline Lactate dehydrogenase A & Ldha & -2 \\
\hline Phosphoglucomutase 1 & Pgm1 & -2 \\
\hline Dihydrolipoamide S-acetyltransferase & Dlat & -2 \\
\hline
\end{tabular}


Table 6 Genes with changed expression in diaphragm of type II and type I (12) diabetic rats that were assigned to specific statistically over-represented gene ontology (GO) terms (Continued)

\begin{tabular}{lll}
\hline Collagen & \\
\hline Collagen, type III, alpha $\mathbf{1}$ & Col3a1 \\
\hline Collagen, type 1, alpha $\mathbf{1}$ & Col1a1 & $-\mathbf{3 . 7}$ \\
\hline Procollagen, type I, alpha $\mathbf{2}$ & Col1a2 & $\mathbf{- 3 . 5}$ \\
\hline Fibrillin 1 & Fbn1 \\
\hline Secreted acidic cysteine rich glycoprotein & Sparc \\
\hline Collagen, type V, alpha 1 & Col5a1 \\
\hline Collagen, type V, alpha 3 & Col5a3 \\
\hline
\end{tabular}

Fold changes in gene expression are represented in the last column. Genes in bold are common between type II and type I.

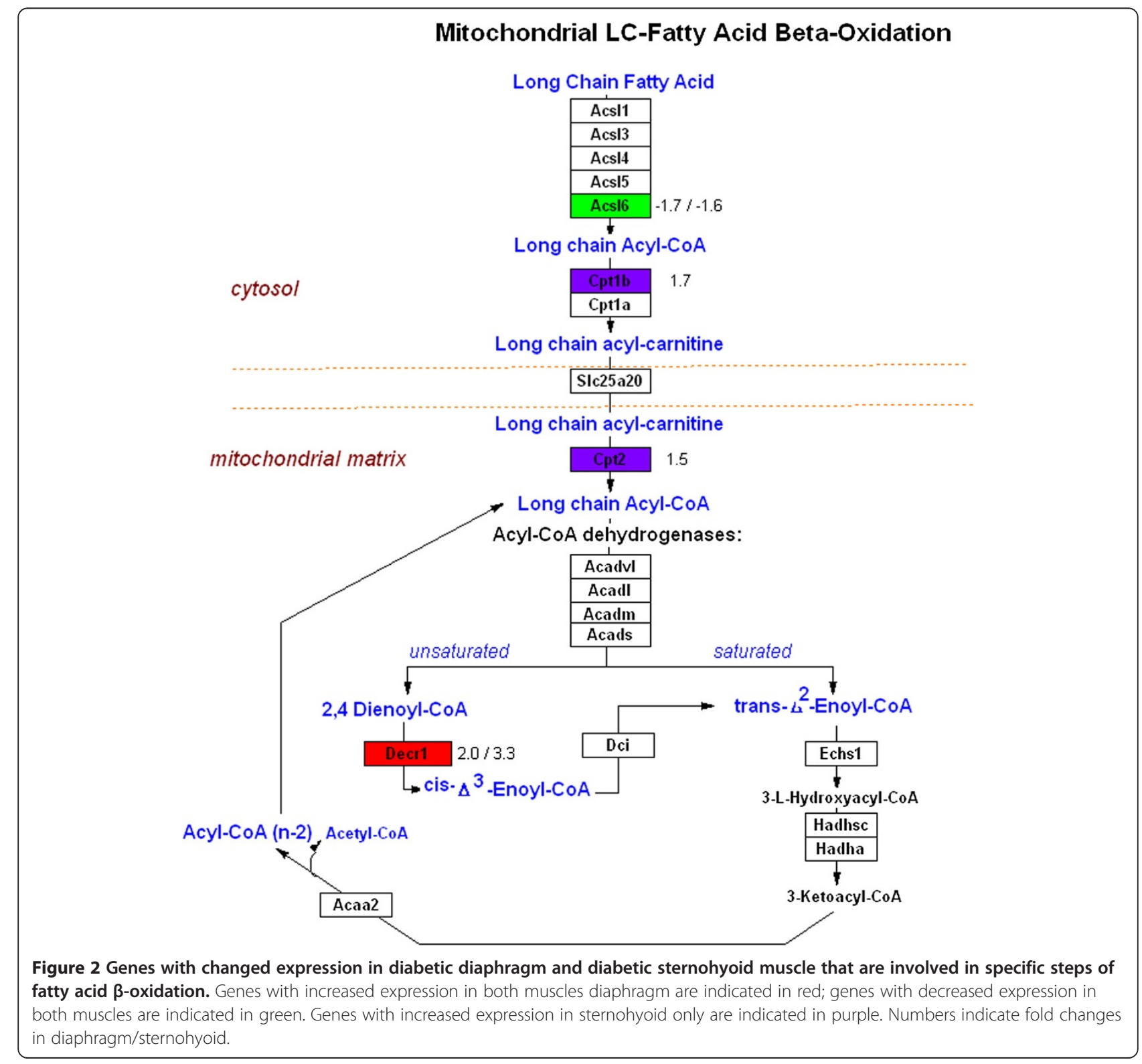


monocarboxylate, Amyla, which binds bicarbonate, Chrnd, which binds acetylcholine, and Ltbp1, which binds TGF-B in order to regulate several collagens. Similar to the present study, Fxyd2, a Na/K ATPase regulator, has increased in human type II diabetic kidneys [72]. Changes in Atp1b2 and Kcnma1 expression have not been found in previous studies. In the present study, Impa2 increased and Acsl6 decreased. However in previous studies, the expression of Impa2 was decreased in type 2 genetically-affected (OLETF) diabetic cornea [75] and the expression of Acsl6 was decreased in streptozotocin-induced diabetic rat diaphragm [12] and heart [33]. The remaining non-calcium ion channel genes in the sternohyoid, Slc16a3, Amy1a, Chrnd and Ltbp1 did not have changed expression in previous studies of diabetes.

\section{Collagen}

In the present study there were several collagen genes which were decreased in type 2 diabetic diaphragm (Col1a1, Col1a2, Col3a1) and sternohyoid (Col1a1, Col1a2, Col5a1), similar to previous studies. In previous studies, all of these collagen genes were significantly decreased in streptozotocin-induced diabetic rat diaphragm with fold changes greater than 2.0 [12]. Col1a2, Col3a1 and Col5a1expression were also decreased in streptozotocin-induced diabetic rat heart [14]. Col1a1 had decreased expression in $\mathrm{db} / \mathrm{db}$ type 2 diabetic mice [76] and streptozotocin-induced diabetic rat gastrocnemius [8]. Col1a2 was decreased in newly forming bone of streptozotocin-induced diabetic mice [77].

\section{Blood circulation}

In the blood circulation group that had significant changes in only the diaphragm, there was only one gene that was not also listed in another group and therefore not mentioned yet. Apelin (Apln) plays a role in normal glucolipidic metabolism [78] and has had conflicting results in previous experiments. The results of the present study agree with the results previous results of low plasma levels in type II diabetic Chinese humans $[79,80]$. There have also been other reports of both increased and decreased Apln levels in patients with type 2 diabetes $[79,81]$.

\section{Oxidoreductase}

In a previous study in streptozotocin-induced diabetic rat diaphragm, we found an increased expression in genes related to oxidative stress [12]. In the present study, there were 3 genes that were not also listed in another GO group (Decr1, Impdh2, Phyhd1). Decr1 catalyzes the conversion of trans-2,3-didehydroacyl-CoA and $\mathrm{NADP}(+)$ into trans, trans-2,3,4,5-tetradehydroacylCoA and NADPH. Similar to the present study, we have previously found an increase in expression in streptozotocin-induced diabetic rat heart [14]. Others have also found a 5 -fold stimulation of activity in the liver mitochondria of streptozotocin-induced diabetic rats [38] and an increased expression in limb skeletal muscle of Zucker diabetic fatty rats [11]. Impdh2 and Phyhd1 have not had changed expression in previous diabetic studies.

\section{Immune \& inflammatory, and response to stress \& wounding}

Most of the genes in these categories had increased expression in the diabetic sternohyoid, similar to a previous study in streptozotocin-induced diabetic liver [82]. However, these increases were completely absent in the diabetic diaphragm in the present study as well as type 1 diabetic diaphragm in our previous study ${ }^{12}$. Some of the sternohyoid genes with increased expression are depicted on the complement activation, classical pathway (Figure 3). One of the genes involved in the pathway is adipsin (Adn). Adipsin assembles with complement factor B to enzymatically cleave complement factor C3 to C3a-des-arg/ASP (acylation stimulating protein), which stimulates triglyceride production in adipose tissue [83]. It is the one complement component that has had changed expression due to diabetes in previous studies. Adipsin has increased in streptozotocin-induced diabetic mouse endothelium [83] and in streptozotocininduced diabetic rat adipose tissue [84]. The complement factors ( $\mathrm{Clqb}, \mathrm{Clqa}, \mathrm{Cfh})$ are also involved in the complement activation classical pathway (Figure 3), but have not changed expression levels due to diabetes in previous studies. Cdkn1a is a cyclin-dependent kinase inhibitor [82]. It regulates cell division by arresting the cell cycle and is induced by oxidative stress $[85,86]$. Cdkn1a has increased expression in cardiac and soleus muscle of streptozotocin-induced diabetic rats [45] and liver of streptozotocin-induced diabetic mice [82].

All of the immune and inflammatory genes in the sternohyoid with increased expression are contained in the stress and wounding group too. The three genes with decreased expression (Dpp4, Mx1 and Spon2) are not contained in the stress and wounding group or any other of the significant GO groups in this study. Dipeptidyl peptidase IV (Dpp4) is a serine protease that exists on the surface of various types of cells and in a soluble form in plasma [87]. Circulating Dpp4 levels have been reported to be both increased [88,89] and decreased [90,91] in type 2 diabetic patients and increased in type I diabetic patients [88]. Dpp4 increases have been measured in many tissues of streptozotocin-induced diabetic rats [92]. Mx1 and Spon2 have had altered gene expression due to diabetes in any previous study. 


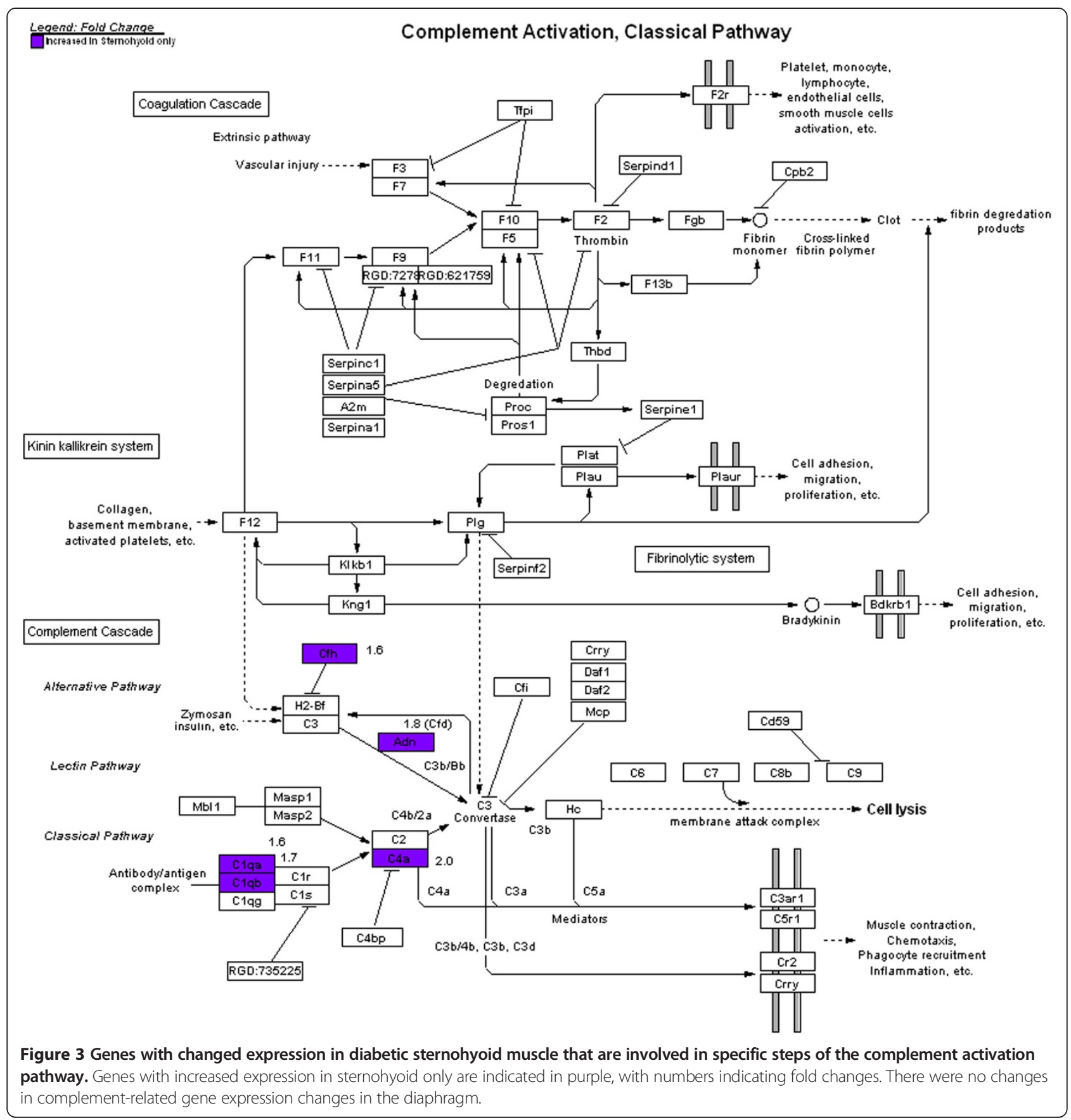

\section{Conclusions}

In conclusion, the current study shows that type 2 diabetes produces significant changes in gene expression of the diaphragm and sternohyoid muscles, many of which were not expected based on previous data on type 1 streptozotocin-induced diabetic diaphragm [12] as well as on both types 1 and type 2 diabetes in other muscle types $[8-11,14,32,93]$. The diaphragm had more gene expression decreases in carbohydrate metabolism due to diabetes than the sternohyoid, while the increases in lipid metabolism genes were similar in both muscles. Thus there was a larger metabolic gene expression shift in the diaphragm than the sternohyoid. However, for several other processes there were more closely shared magnitudes of gene expression changes (muscle contraction, ion transport, collagen). In addition, there were several gene expression changes in the diabetic sternohyoid that were not present in the diaphragm (immune \& inflammatory, response to stress \& wounding) and vice versa (oxidoreductase activity, blood circulation). The 
upper airway muscles and diaphragm therefore have targets in common as well as individual targets for future treatment strategies aimed at improving muscle function in diabetes and obstructive sleep apnea.

\section{Additional file}

Additional file 1: Complete list of genes with at least \pm 1.5 -fold changed expression in diaphragm and sternohyoid of diabetic animals. Fold changes (FC) in gene expression are represented in the last column.

\section{Competing interests}

The authors declare that they have no competing interests.

\section{Authors' contributions}

MM carried out studies, performed the statistical analysis and helped to draft the manuscript. EvL conceived of the study and participated in its design and coordination and helped to draft the manuscript. Both authors read and approved the final manuscript.

\section{Acknowledgements}

This study was supported by a grant from the Department of Veterans Affairs (Veterans Health Administration). The Gene Expression Array Core Facility of the Comprehensive Cancer Center of Case Western Reserve University and University Hospitals of Cleveland was a valuable part of this study by processing the gene arrays and PCR.

\section{Author details}

${ }^{1}$ Pulmonary, Critical Care \& Sleep Division, Department of Medicine, Louis Stokes, Cleveland, USA. ²Department of Veterans Affairs Medical Center, Cleveland, $\mathrm{OH} 44106$, USA. ${ }^{3}$ Case Western Reserve University, Cleveland, $\mathrm{OH}$ 44106, USA.

Received: 2 May 2013 Accepted: 26 September 2013 Published: 7 October 2013

\section{References}

1. Almeida S, Riddell MC, Cafarelli E: Slower conduction velocity and motor unit discharge frequency are associated with muscle fatigue during isometric exercise in type 1 diabetes mellitus. Muscle Nerve 2008, 37:231-240

2. Cotter M, Cameron NE, Lean DR, Robertson S: Effects of long-term streptozotocin diabetes on the contractile and histochemical properties of rat muscles. Q J Exp Physiol 1989, 74:65-74.

3. McGuire M, MacDermott M: The influence of streptozotocin-induced diabetes and the antihyperglycaemic agent metformin on the contractile characteristics and the membrane potential of the rat diaphragm. Exp Physio/ 1998, 83:481-487.

4. Scano G, Filippelli M, Romagnoli I, Mancini M, Misuri G, Duranti R, Rosi E: Hypoxic and hypercapnic breathlessness in patients with type I diabetes mellitus. Chest 2000, 117:960-967.

5. Wanke T, Formanek D, Auinger M, Popp W, Zwick H, Irsigler K: Inspiratory muscle performance and pulmonary function changes in insulindependent diabetes mellitus. Am Rev Resp Dis 1991, 143:97-100.

6. Wanke T, Lahrmann H, Auinger M, Merkle M, Formanek D, Ogris E, Irsigler K, Zwick H: Endogenous opiod system during inspiratory loading in patients with type 1 diabetes. Am Rev Respir Dis 1993, 148:1335-1340.

7. McGuire M, Dumbleton M, MacDermott M, Bradford A: Contractile and electrical properties of sternohyoid muscle in streptozotocin diabetic rats. Clin Exp Pharmacol Physiol 2001, 28:184-187.

8. Lecker SH, Jagoe RT, Gilbert A, Gomes M, Baracos V, Bailey J, Price SR, Mitch WE, Goldberg AL: Multiple types of skeletal muscle atrophy involve a common program of changes in gene expression. FASEB J 2004 18:39-51.

9. Sreekumar R, Halvatsiotis P, Schimke JC, Nair KS: Gene expression profile in skeletal muscle of type 2 diabetes and the effect of insulin treatment Diabetes 2002, 51:1913-1920.
10. Suh $Y H$, Kim Y, Bang JH, Choi KS, Lee JW, Kim WH, Oh TJ, An S, Jung MH: Analysis of gene expression profiles in insulin-sensitive tissues from pre-diabetic and diabetic Zucker diabetic fatty rats. J Mol Endocrinol 2005, 34:299-315.

11. Voss MD, Beha A, Tennagels N, Tschank G, Herling AW, Quint M, Gerl M, Metz-Weidmann C, Haun G, Korn M: Gene expression profiling in skeletal muscle of Zucker diabetic fatty rats: implications for a role of stearoylCoA desaturase 1 in insulin resistance. Diabetologia 2005, 48:2622-2630.

12. van Lunteren $\mathrm{E}$, Moyer M: Gene expression profiling in the type 1 diabetes rat diaphragm. PLoS One 2009, 4:E7832.

13. van Lunteren E, Spiegler S, Moyer M: Differential expression of lipid and carbohydrate metabolism genes in upper airway versus diaphragm muscle. Sleep 2010, 33:363-370.

14. van Lunteren $\mathrm{E}$, Moyer M: Oxidoreductase, morphogenesis, extracellular matrix and calcium ion binding gene expression in streptozotocininduced diabetic rat heart. Am J Physiol Endocrinol Metab 2007, 293:E759-E768

15. van Lunteren E, Moyer M: Altered diaphragm action potentials in Zucker diabetic fatty (ZDF) rats. Respir Physiol Neurobiol 2006, 153:157-165.

16. van Lunteren $\mathrm{E}$, Spiegler S, Moyer M: Contrast between cardiac left ventricle and diaphragm muscle in expression of genes involved in carbohydrate and lipid metabolism. Respir Physiol Neurobiol 2008, 161:41-53.

17. Ishwaran H, Rao JS: Detecting differentially expressed genes in microarrays using Bayesian model selection. J Am Stat Assoc 2003, 98:438-455

18. Dennis G, Sherman BT, Hosack DA, Yang J, Gao W, Lane HC, Lempicki RA: DAVID: data base for annotation, visualization, and integrated discovery. Genome Biol 2003, 4:R60.

19. Hosack DA, Dennis G, Sherman BT, Lane HC, Lempicki RA: Identifying biological themes within lists of genes with EASE. Genome Biol 2003 4:R70.

20. Beatty $\mathrm{CH}$, Peterson RD, Bocek RM, West ES: Acetoacetate and glucose uptake by diaphragm and skeletal muscle from control and diabetic rats. J Biol Chem 1959, 234:11-15.

21. Beloff-Chain A, Chain EB, Rookledge KA: The influence of insulin and of contraction on glucose metabolism in the perfused diaphragm muscle from normal and streptozotocin-treated rats. Biochem J 1971, 125:97-103.

22. Beloff-Chain A, Rookledge KA: The metabolism of glucose in diaphragm muscle from normal rats, from streptozotocin-treated diabetic rats and from rats treated with anti-insulin serum. Biochem J 1968, 110:529-532.

23. Caterson ID, Fuller SJ, Randle PJ: Effect of the fatty acid oxidation inhibitor 2-tetradecylglycidic acid on pyruvate dehydrogenase complex activity in starved and alloxan-diabetic rats. Biochem J 1982, 208:53-60.

24. Foster JM, Villee CA: Pyruvate and acetate metabolism in the isolated rat diaphragm. J Biol Chem 1954, 211:797-808.

25. Garland PB, Newsholme EA, Randle PJ: Regulation of glucose uptake by muscle. 9. Effects of fatty acids and ketone bodies, and of alloxandiabetes and starvation, on pyruvate metabolism and on lactatepyruvate and L-glycerol 3-phosphate-dihydroxyacetone phosphate concentration ratios in rat heart and rat diaphragm muscles. Biochem J 1964, 93:665-678.

26. Ianuzzo CD, Noble EG, Hamilton N, Dabrowski B: Effects of streptozotocin diabetes, insulin treatment, and training on the diaphragm. J Appl Physiol 1982, 52:1471-1475.

27. Randle PJ, Newsholme EA, Garland PB: Regulation of glucose uptake by muscle. 8. Effects of fatty acids, ketone bodies and pyruvate, and of alloxan-diabetes and starvation, on the uptake and metabolic fate of glucose in rat heart and diaphragm muscles. Biochem J 1964, 93:652-665.

28. Chorváthová V, Ondreicka R, Ozdin L, Dzúrik R: Metabolism of palmitate-1-14C in the tissues of rats with streptozotocin diabetes. Physiol Bohemoslov 1981, 30:259-266.

29. Garland PB, Randle PJ: Regulation of glucose uptake by muscles. 10 . Effects of alloxan-diabetes, starvation, hypophysectomy and adrenalectomy, and of fatty acids, ketone bodies and pyruvate, on the glycerol output and concentrations of free fatty acids, long-chain fatty acyl-coenzyme A, glycerol phosphate and citrate-cycle intermediates in rat heart and diaphragm muscles. Biochem J 1964, 93:678-687.

30. Stearns SB, Tepperman HM, Tepperman J: Studies on the utilization and mobilization of lipid in skeletal muscles from streptozotocin-diabetic and control rats. J Lipid Res 1979, 20:654-662. 
31. Wall SR, Lopaschuk GD: Glucose oxidation rates in fatty acid-perfused isolated working hearts from diabetic rats. Biochim Biophys Acta 1989, 1006:97-103.

32. Gerber LK, Aronow BJ, Matlib MA: Activation of a novel long-chain free fatty acid generation and export system in mitochondria of diabetic rat hearts. Am J Physiol Cell Physiol 2006, 291:1198-1207.

33. Durgan DJ, Smith JK, Hotze MA, Egbejimi O, Cuthbert KD, Zaha VG, Dyck J, Abel ED, Young ME: Distinct transcriptional regulation of long-chain acylCoA synthetase isoforms and cytosolic thioesterase 1 in the rodent heart by fatty acids and insulin. Am J Physiol Heart Circ Physiol 2006, 290: $\mathrm{H} 2480-\mathrm{H} 2497$

34. Kahn BB, Alquier T, Carlin D, Hardie DG: AMP-activated protein kinase: Ancient energy gauge provides clues to modern understanding of metabolism. Cell Metabol 2005, 1:15-25.

35. Kinlaw WB, Quinn JL, Wells WA, Roser-Jones C, Moncur JT: Minireview: spot 14: a marker of aggressive breast cancer and a potential therapeutic target. Endocrinology 2006, 147:4048-4055.

36. LaFave LT, Augustin LB, Mariash CN: Minireview: S14: Insights from knockout mice. Endocrinology 2006, 147:4044-4047.

37. Bennati AM, Schiavoni G, Franken S, Piobbico D, Della Fazia MA, Caruso D, De Fabiani E, Benedetti L, Cusella De Angelis MG, Gieselmann V, Servillo G, Beccari T, Roberti R: Disruption of the gene encoding 3 $\beta$-hydroxysterol $\Delta^{14}$-reductase (Tm7sf2) in mice does not impair cholesterol biosynthesis. FEBS J 2008, 275:5034-5047.

38. Osmundsen $\mathrm{H}$, Bjørnstad $\mathrm{K}$ : Inhibitory effects of some long-chain unsaturated fatty acids on mitochondrial $\beta$-oxidation. Biochem J 1985, 230:329-337.

39. Arikawa E, Ma RCW, Isshiki K, Luptak I, He Z, Yasuda Y, Maeno Y, Patti ME, Weir GC, Harris RA, Zammit VA, Tian R, King GL: Effects of insulin replacements, inhibitors of angiotensin, and PKC $\beta$ 's actions to normalize cardiac gene expression and fuel metabolism in diabetic rats. Diabetes 2007, 56:1410-1420.

40. Mishra R, Emancipator SN, Miller C, Kern T, Simonson MS: Adipose differentiation-related protein and regulators of lipid homeostasis identified by gene expression profiling in the murine $\mathrm{db} / \mathrm{db}$ diabetic kidney. Am J Physiol Renal Physiol 2004, 286:913-921.

41. Nordström EA, Rydén M, Backlund EC, Dahlman I, Kaaman M, Blomqvist L, Cannon B, Nedergaard J, Arner P: A human-specific role of celldeathinducing DFFA (DNA fragmentation factor-a)-like effector A (CIDEA) in adipocyte lipolysis and obesity. Diabetes 2005, 54:1726-1734.

42. Zhou Z, Toh SY, Chen Z, Guo K, Ng CP, Ponniah S, Lin S-C, Hong W, Li P: Cidea-deficient mice have lean phenotype and are resistant to obesity. Nat Genet 2003, 35:49-56.

43. Carey AL, Petersen EW, Bruce CR, Southgate RJ, Pilegaard H, Hawley JA, Pedersen BK, Febbraio MA: Discordant gene expression in skeletal muscle and adipose tissue of patients with type 2 diabetes: effect of interleukin6 infusion. Diabetologia 2006, 49:1000-1007.

44. Depre C, Young ME, Ying J, Ahuja HS, Han Q, Garza N, Davies PJA, Taegtmeyer H: Streptozotocin-induced changes in cardiac gene expression in the absence of severe contractile dysfunction. J Mol Cell Cardiol 2000, 32:985-996.

45. Stavinoha MA, RaySpellicy JW, Essop MF, Graveleau C, Abel ED, Hart-Sailors ML, Mersmann HJ, Bray MS, Young ME: Evidence for mitochondrial thioesterase 1 as a peroxisome proliferators-activated receptor-a -regulated gene in cardiac and skeletal muscle. Am J Physiol Endocrinol Metab 2004, 287:888-895.

46. Chiu H-C, Kovacs A, Blanton RM, Han X, Courtois M, Weinheimer C, Yamada KA, Brunet S, Xu H, Nernonne JM, Welch MJ, Fettig NM, Sharp TL, Sambandam N, Olson KM, Ory DS, Schaffer JE: Transgenic expression of fatty acid transport protein 1 in the heart causes lipotoxic cardiomyopathy. Circ Res 2005, 96:225-233.

47. James DE, Brown R, Navarro J, Pilch PF: Insulin-regulatable tissues express a unique insulin-sensitive glucose transport protein. Nature 1988, 333:183-185.

48. Shoghi Kl, Gropler RJ, Sharp T, Herrero P, Fettig N, Su Y, Mitra MS, Kovacs A, Finck BN, Welch MJ: Time course of alterations in myocardial glucose utilization in the zucker diabetic fatty rat with correlation to gene expression of glucose transporters: a small-animal PET investigation. J Nucl Med 2008, 49:1320-1327.

49. Gaster M, Staehr $P$, Beck-Nielsen H, Schroder HD, Handberg A: Glut3 is reduced in slow muscle fibers of type 2 diabetic patients: is insulin resistance in type 2 diabetes a slow type 1 fiber disease? Diabetes 2001, 50:1324-1329.

50. Yuan M, Konstantopoulos N, Lee J, Hansen L, Li ZW, Karin M, Shoelson SE: Reversal of obesity- and diet-induced insulin resistance with salicylates or targeted disruption of Ikkbeta. Science 2001, 293:1673-1677.

51. Meng M, Geisler M, Johansson H, Harholt J, Scheller HV, Mellerowicz EJ, Kleczkowski LA: UDP-glucose pyrophosphorylase is not rate limiting, but is essential in arabidopsis. Plant Cell Physiol 2009, 50:998-1011.

52. Sudo T, Ishii A, Asami J, Uematsu Y, Saitoh M, Nakamura A, Tada N, Ohnuki T, Komurasaki T, Nakagawa J: Transgenic mice over-expressing dicarbonyl/ L-xylulose reductase gene crossed with KK-Ay diabetic model mice: an animal model for the metabolism of renal carbonyl compounds. Exp Anim 2005, 54:385-394.

53. Hue $\mathrm{L}$, Rider $\mathrm{MH}$ : Role of fructose-2,6-bisphosphate in the control of glycolysis in mammalian tissues. Biochem J 1987, 245:313-324.

54. Okar DA, Manzano A, Navarro-Sabate A, Riera L, Bartrons R, Lange AJ: PFK-2/FBPase-2: maker and breaker of the essential biofactor fructose-2, 6-bisphosphate. Trends Biochem Sci 2001, 26:30-35.

55. Pilkis SJ, Claus TH, Kurland IJ, Lange AJ: 6-Phosphofructro-2-kinase/ fructose-2 6-bisphosphate: a metabolic signaling enzyme. Annu Rev Biochem 1995, 64:799-835.

56. van Schaftingen E: Fructose 2,6-bisphosphate. Adv Enzymol Relate Areas Mol Biol 1987, 59:315-395.

57. Wu C, Khan SA, Peng L-J, Lange AJ: Roles for fructose-2,6-bisphosphate in the control of fuel metabolism: beyond its allosteric effects on glycolytic and gluconeogenic enzymes. Advan Enzyme Regul 2006, 46:72-88.

58. Lehti TM, Silvennoinen M, Kivelä $R$, Kainulainen $H$, Komulainen J: Effects of streptozotocin-induced diabetes and physical training on gene expression of titin-based stretch-sensing complexes in mouse striated muscle. Am J Physiol Endocrinol Metab 2007, 292:E533-E542.

59. Endo T, Onaya T: Parvalbumin is reduced in the peripheral nerves of diabetic rats. J Clin Invest 1986, 78:1161-1164.

60. Haghighi K, Chen G, Sato Y, Fan GC, Kolokathis F, Pater L, Paraskevaidis I, Jones WK, Dorn GW II, Kremastinos DT, Kranias EG: A human phospholamban promoter polymorphism in dilated cardiomyopathy alters transcriptional regulation by glucocorticoids. Human Mutat 2008, 29:640-647.

61. Kim HW, Ch YS, Lee HR, Park SY, Kim YH: Diabetic alterations in cardiac sarcoplasmic reticulum $\mathrm{Ca}^{2+}$-ATPase and phospholamban protein expression. Life Sci 2001, 70:367-379.

62. Zhong Y, Ahmed S, Grupp IL, Matlib MA: Altered SR protein expression associated with contractile dysfunction in diabetic rat hearts. Am J Physiol Heart Circ Physiol 2001, 281:1137-1147.

63. Vasanji Z, Dhalla NS, Netticadan T: Increased inhibition of SERCA2 by phospholamban in the type I diabetic heart. Mol Cell Biochem 2004, 261:245-249.

64. Alzugaray ME, García M, Del Zotto HH, Raschia MA, Palomeque J, Rossi J, Gagliardino JJ, Flores LE: Changes in islet plasma membrane calciumATPase activity and isoform expression induced by insulin resistance. Arch Biochem Biophys 2009, 490:17-23.

65. Wieteska-Skrzeczynska W, Grzelkowska-Kowalczyk K, Jank M, Maciejewski H: Transcriptional dysregulation of skeletal muscle protein metabolism in streptozotocin-diabetic mice. J Physiol Pharmacol Supp/ 2009, 1:29-39.

66. Nairn AC, Bhagat B, Palfrey HC: Identification of calmodulin-dependent protein kinase III and its major Mr 100,000 substrate in mammalian tissues. Proc Natl Acad Sci U S A 1985, 82:7939-7943.

67. Redpath NT, Proud CG: Purification and phosphorylation of elongation factor-2 kinase from rabbit reticulocytes. Eur J Biochem 1993, 212:511-520.

68. Ryazanov AG, Natapov PG, Shestakova EA, Severin FF, Spirin AS: Phosphorylation of elongation factor 2: the fifth Ca2+/calmodulin-dependent system of protein phosphorylation. Biochimie (Paris) 1988, 70:619-626.

69. Fukaya N, Mochizuki K, Shimada M, Goda T: The a-glucosidase inhibitor miglitol decreases glucose fluctuations and gene expression of inflammatory cytokines induced by hyperglycemia in peripheral leukocytes. Nutrition 2009, 25:657-667.

70. Gardai SJ, McPhillips KA, Frasch SC, Janssen WJ, Starefeldt A, Murphy-Ulrich JE, Bratton DL, Oldenborg PA, Michalak M, Henson PM: Cell-surface calretuculin initiates clearance of viable or apoptotic cells through trans-activation of LRP on the phagocyte. Cell 2005, 123:321-334.

71. Strickland DK, Gonias SL, Argraves WS: Diverse roles for the LDL receptor family. Trends Endocrinol Metab 2002, 13:66-74. 
72. Baelde HJ, Eikmans M, Doran PP, Lappin DW, de Herr E, Bruijn JA: Gene expression profiling in glomeruli from human kidneys with diabetic nephropathy. Am J Kidney Dis 2004, 43:636-650.

73. Leung JC, Chan LY, Tsang AW, Tang SC, Lai KN: Differential expression of aquaporins in the kidneys of streptozotocin-induced diabetic mice. Nephrology (Carlton) 2005, 10:63-72

74. Dt W, Yau SK, Mee AP, Mawer EB, Miller CA, Garland HO, Riccardi D: Functional, molecular, and biochemical characterization of streptozotocin-induced diabetes. J Am Soc Nephrol 2001, 12:779-790.

75. Lee JE, Lee JS, Hwang SH: Microarray for genes associated with signal transduction in diabetic OLETF keratocytes. Korean J Ophthalmol 2007 21:111-119.

76. Nielsen JM, Kristiansen SB, Nørregaard R, Andersen CL, Denner $L$, Nielsen $T$, Flyvbjerg A, Bøtker HE: Blockage of receptor for advanced glycation end products prevents development of cardiac dysfunction in $\mathrm{db} / \mathrm{db}$ type 2 diabetic mice. Eur J Heart Fail 2009, 11:638-647.

77. Fowlkes JL, Bunn RC, Liu L, Wahl EC, Coleman HN, Cockrell GE, Perrien DS, Lumpkin CK Jr, Thrailkill KM: Runt-related transcription factor 2 (RUNX2) and RUNX2-related osteogenic genes are down-regulated throughout osteogenesis in type 1 diabetes mellitus. Endocrinology 2008, 149:1697-1704.

78. Ladeiras-Lopes R, Ferreira-Martins J, Leite-Moreira AF: The apelinergic system: the role played in human physiology and pathology and potential therapeutic applications. Arq Bras Cardiol 2008, 90:343-349.

79. Erdeem G, Dogru T, Tasci I, Sonmex A, Tapan S: Low plasma apelin levels in newly diagnosed type 2 diabetes mellitus. Exp Clin Endocrinol Diabetes 2008, 116:289-292

80. Zhang Y, Shen C, Li X, Ren G, Fan X, Ren F, Zhang N, Sun J, Yang J: Low plasma apelin in newly diagnosed type 2 diabetes in Chinese people. Diabetes Care 2009, 32:e150.

81. Li L, Yang G, Li Q, Tang Y, Yang M, Yang H, Li K: Changes and relations of circulating visfatin, apelin, and resistin levels in normal, impaired glucose tolerance, and type 2 diabetic subjects. Exp Clin Endocrinol Diabetes 2006, 114:544-548.

82. Kobori M, Masumoto S, Akimoto Y, Takahashi Y: Dietary quercetin alleviates diabetic symptoms and reduces streptozotocin-induced disturbance of hepatic gene expression in mice. Mol Nutr Food Res 2009 53:859-868.

83. Maresh JG, Shohet RV: In vivo endothelial gene regulation in diabetes. Cardiovasc Diabetol 2008, 7:8.

84. Flier JS, Cook KS, Usher P, Spiegelman BM: Severely impaired adipsin expression in genetic and acquired obesity. Science 1987, 237:405-408.

85. Hershenson MB: $\mathrm{p} 21^{\text {waf- } 1 / \mathrm{Cip}-1}$ and the prevention of oxidative stress. Am J Physiol Lung Cell Mol Physiol 2004, 286:L502-L505.

86. Lunz JG III, Tsuji H, Nozaki I, Murase N, Demetris AJ: An inhibitor of cyclin-dependent kinase, stress-induced p2 $1^{\text {waf-1/Cip-1 }}$, mediates hepatocyte mito-inhibition during the evolution of cirrhosis. Hepatology 2005, 41:1262-1271.

87. Mentlein R: Dipeptidyl-peptidase IV (CD26)-role in the inactivation of regulatory peptides. Regul Pept 1999, 85:9-24

88. Mannucci E, Pala L, Ciani S, Bardini G, Pezzatini A, Sposato I, Cremasco F, Ognibene A, Rotella C: Hyperglycaemia increases dipeptidyl peptidase IV activity in diabetes mellitus. Diabetologia 2005, 48:1168-1172.

89. Ryskjaer J, Deacon CF, Carr RD, Krarup T, Madsbad S, Holst J, Vilsboll T: Plasma dipeptidyl peptidase-IV activity in patients with type-2 diabetes mellitus correlates positively with HbAlc levels, but is not acutely affected by food intake. Eur J Endocrinol 2006, 155:485-493.

90. McKillop AM, Duffy NA, Lindsay JR, O'Harte FRM, Bell PM, Flatt PR: Decreased dipeptidyl peptidase-IV activity and glucagons-like peptide-1 (7-36) amide degradation in type 2 diabetic subjects. Diabetes Res Clin Pract 2008, 79:79-85.

91. Meneilly GS, Demuth HU, McIntosh CHS, Pederson RA: Effect of ageing and diabetes on glucose-dependent insulinotropic polypeptide and dipeptidylpeptidase IV responses to oral glucose. Diabet Med 2000 $17: 346-350$
92. Kirino Y, Sato Y, Kamimoto T, Kawazoe K, Minakuchi K, Nakahori Y: Interrelationship of dipeptidyl peptidase IV (DPP4) with the development of diabetes, dyslipidaemia and nephropathy: a streptozotocin-induced model using wild-type and DPP4-deficient rats. J Endocrinol 2009, 200:53-61.

93. Knoll KE, Pietrusz JL, Liang M: Tissue-specific transcriptome responses in rats with early streptozotocin-induced diabetes. Physiol Genomics 2002, 21:222-229.

doi:10.1186/1472-6823-13-43

Cite this article as: van Lunteren and Moyer: Gene expression of sternohyoid and diaphragm muscles in type 2 diabetic rats. BMC Endocrine Disorders 2013 13:43.

\section{Submit your next manuscript to BioMed Central and take full advantage of:}

- Convenient online submission

- Thorough peer review

- No space constraints or color figure charges

- Immediate publication on acceptance

- Inclusion in PubMed, CAS, Scopus and Google Scholar

- Research which is freely available for redistribution

Submit your manuscript at www.biomedcentral.com/submit
C Biomed Central 